\title{
Contribution to the flora of Asian and European countries: new national and regional vascular plant records, 9
}

\author{
Marcin NOBIS $^{1, *}$, Jolanta MARCINIUK ${ }^{2}$, Paweł MARCINIUK ${ }^{2}$, Mateusz WOLANIN ${ }^{3}$, Gergely KIRÁLY ${ }^{4}$, \\ Arkadiusz NOWAK ${ }^{5,6}$, Beata PASZKO ${ }^{7}$, Ewelina KLICHOWSKA ${ }^{1}$, Gonzalo MORENO-MORAL ${ }^{8}$, \\ Renata PIWOWARCZYK ${ }^{9}$, Óscar SÁNCHEZ-PEDRAJA ${ }^{10}$, Anna WRÓBEL ${ }^{1}$, Irina N. EGOROVA ${ }^{11}$, Pavol Eliaš JUN. ${ }^{12}$, \\ Denis A. KRIVENKO ${ }^{11}$, Igor V. KUZMIN ${ }^{13}$, Georgy A. LAZKOV ${ }^{14}$, Giacomo MEI ${ }^{15}$, Agnieszka NOBIS ${ }^{1}$, \\ Marina V. OLONOVA ${ }^{16}$, Robert J. SORENG ${ }^{17}$, Adriano STINCA ${ }^{18}$, Vladimir M. VASJUKOV ${ }^{19}$, Nikita A. VERSHININ ${ }^{13}$ \\ ${ }^{1}$ Institute of Botany, Faculty of Biology, Jagiellonian University, Kraków, Poland \\ ${ }^{2}$ Institute of Biology, Faculty of Natural Sciences, Siedlce University of Natural Sciences and Humanities, Siedlce, Poland \\ ${ }^{3}$ Department of Botany, Institute of Biology and Biotechnology, University of Rzeszów, Rzeszów, Poland \\ ${ }^{4}$ Institute of Silviculture and Forest Protection, Faculty of Forestry, University of Sopron, Hungary \\ ${ }^{5}$ Botanical Garden-Center for Biological Diversity Conservation, Polish Academy of Sciences, Warsaw, Poland \\ ${ }^{6}$ Opole University, Opole, Poland \\ ${ }^{7}$ Department of Vascular Plants, W. Szafer Institute of Botany, Polish Academy of Sciences, Kraków, Poland \\ ${ }^{8}$ Santa Clara, Santander (Cantabria), Spain \\ ${ }^{9}$ Department of Microbiology and Parasitology, Institute of Biology, Jan Kochanowski University, Kielce, Poland \\ ${ }^{10}$ Grupo Botánico Cantábrico (GBC), Liérganes (Cantabria), Spain \\ ${ }^{11}$ Siberian Institute of Plant Physiology \& Biochemistry, Siberian Branch of Russian Academy of Sciences, Irkutsk, Russia \\ ${ }^{12}$ Department of Botany, Slovak University of Agriculture in Nitra, Nitra, Slovakia \\ ${ }^{13}$ Tyumen State University, Tyumen, Russia \\ ${ }^{14}$ Laboratory of Flora, Institute of Biology, Kyrgyz Academy of Sciences, Bishkek, Kyrgyzstan \\ ${ }^{15}$ Department of Agricultural, Food and Environmental Sciences, Marche Polytechnic University, Ancona, Italy \\ ${ }^{16}$ Institute of Biology, National Research Tomsk State University, Tomsk, Russia \\ ${ }^{17}$ National Museum of Natural History, Smithsonian Institution, Washington, DC, USA \\ ${ }^{18}$ Department of Environmental, Biological and Pharmaceutical Sciences and Technologies, \\ University of Campania Luigi Vanvitelli, Caserta, Italy \\ ${ }^{19}$ Institute of Ecology of the Volga River Basin, Russian Academy of Sciences, Tolyatti, Russia
}

Received: 29.08 .2019

- $\quad$ Accepted/Published Online: 19.03 .2020

- $\quad$ Final Version: 16.07 .2020

\begin{abstract}
The paper presents new records for 39 vascular plant species from eight Eurasian countries. Aniselytron treutleri (Poaceae), Hackelochloa granularis (Poaceae), Melica kozlovii (Poaceae) and Melica nutans (Poaceae) are reported from China; Dichondra micrantha (Convolvulaceae) from Hungary; Orobanche serbica (Orobanchaceae) and Viscum album subsp. austriacum (Santalaceae) from Italy; Petrorhagia prolifera (Caryophyllaceae), Puccinellia schischkinii and Stipa pulcherrima (Poaceae) from Kyrgyzstan; Megadenia speluncarum (Brassicaceae), Phelipanche lavandulacea (Orobanchaceae), Solanum physalifolium (Solanaceae), Thymus lenensis (Lamiaceae) from Russia; Rubus phoenicolasius (Rosaceae) from Slovakia; Atraphaxis karataviensis (Polygonaceae) from Tajikistan; as well as Rubus austroslovacus and R. crispomarginatus (Rosaceae) in addition to Taraxacum acervatulum, T. aequilobum, T. amplum, T. ancistrolobum, T. bellicum, T. collarispinulosum, T. copidophyllum, T. corynodes, T. dentatum, T. gelertii, T. infuscatum, T. ingens, T. lucidum, T. paucilobum, T. plumbeum, T. portentosum, T. sinuatum, T. subhuelphersianum, T. telmatophilum, T. undulatiforme and T. undulatum (Asteraceae) from Ukraine. For each species synonyms, general distribution, habitat preferences, notes on taxonomy with remarks concerning recognition and distinction of the species from the most similar taxa occurring in a given country, as well as a list of recorded localities (often far from the previously known areas) are presented.
\end{abstract}

Key words: Chorology, taxonomy, native species, alien species, Asia, Europe

\section{Introduction}

Although, it might seem that good knowledge on the general distribution of vascular plants has been attained

*Correspondence: m.nobis@uj.edu.pl for the Eurasian flora, there are still many regions where new plant species are discovered (e.g. Lazkov \& Sennikov, 2017; Nobis et al., 2018; Raab-Straube \& Raus, 2019a, 
2019b). The present paper is dedicated to new national and regional vascular plant records, to broad our knowledge on their distribution and taxonomy.

During the field exploration across the vast area of European and Asian countries, as well as during taxonomic revisions of herbarium material of different groups of vascular plants, we found some species which are new to the floras of particular countries or its significant regions (provinces or republics). The purpose of this paper is to report new records for 39 vascular plant species from eight Eurasian countries. Four taxa (Aniselytron treutleri, Hackelochloa granularis, Melica kozlovii, Melica nutans) are reported from China, one (Dichondra micrantha) from Hungary, two (Orobanche serbica, Viscum album subsp. austriacum) from Italy, three (Petrorhagia prolifera, Puccinellia schischkinii, Stipa pulcherrima) from Kyrgyzstan, four (Megadenia speluncarum, Phelipanche lavandulacea, Solanum physalifolium, Thymus lenensis) from Russia, one (Rubus phoenicolasius) from Slovakia, one (Atraphaxis karataviensis) from Tajikistan, and 23 (Rubus austroslovacus, Rubus crispomarginatus, Taraxacum acervatulum, Taraxacum aequilobum, Taraxacum amplum, Taraxacum ancistrolobum, Taraxacum bellicum, Taraxacum collarispinulosum, Taraxacum copidophyllum, Taraxacum corynodes, Taraxacum dentatum, Taraxacum gelertii, Taraxacum infuscatum, Taraxacum ingens, Taraxacum lucidum, Taraxacum paucilobum, Taraxacum plumbeum, Taraxacum portentosum, Taraxacum sinuatum, Taraxacum subhuelphersianum, Taraxacum telmatophilum, Taraxacum undulatiforme, Taraxacum undulatum) from Ukraine. This work aims to contribute to a better understanding of spreading directions of particular vascular plants as well as species composition of selected countries and/or geographical regions of Eurasia.

\section{Materials and methods}

Field researches were conducted in 2015-2019 in addition to revision of herbarium specimens preserved at BP, KRA, KRAM, IRK, LE, MW, NS, OPUN, PE, PR, SLO, TK, WSRP.

For each species synonyms, general distribution, habitat preferences, taxonomy with remarks on recognition and differentiation the species from the most similar occurring in a given country, as well as a list of localities recorded (often far from the previously known areas) were presented. The taxa presented below are given in alphabetic order in two groups, for Asian and for European countries.

\section{Results}

New records for Asian countries

Aniselytron treutleri (Kuntze) Soják (Poaceae)

Synonyms: Milium treutleri Kuntze, Aulacolepis treutleri (Kuntze) Hack. (nom. illeg.), Calamagrostis treutleri
(Kuntze) U. Shukla, Deyeuxia treutleri (Kuntze) Stapf, Neoaulacolepis treutleri (Kuntze) Rauschert.

Contributor - Beata Paszko

Distribution and habitat

Aniselytron treutleri (Kuntze) Soják was recorded from Bhutan, China, Northeastern India (Darjeeling, Sikkim), Indonesia (N Sumatra), Japan, Malaysia (Sabah), North Myanmar, Philippines (Luzon), and North Vietnam (Merrill and Merritt, 1910; Korthof and Veldkamp, 1984; Noltie, 2000; Kress et al., 2003; Lu and Phillips, 2006). In China, it was previously known from the following provinces: Fujian, Guangxi, Guizhou, Hubei, Sichuan, Taiwan, and Yunnan (Lu and Phillips, 2006). Here, new records of $A$. treutleri are reported from the Xinning County of Hunan and from Anfu County of Jiangxi. The species grows in shaded, rocky places in midmontane to upper montane areas, often in ravines (Korthof and Veldkamp, 1984; Lu and Phillips, 2006).

\section{Taxonomic notes}

The concept of Aniselytron Merrill proposed by Korthof and Veldkamp (1984), comprising two species (Aniselytron agrostoides (Kuntze) Soják and Aniselytron treutleri Merrill), is usually used in some floristic treatments and checklists in southeast Asia [Hsu et al., 2000; Kress et al., 2003; Lu and Phillips, 2006]. At the same time, Aniselytron was placed in synonymy of Calamagrostis Adanson by Clayton and Renvoize (1986). The latter treatment has been followed by Shukla (1996) for northeastern India and Noltie (2000) for Bhutan. An illegitimate genus name, Aulacolepis Hackel, was also sometimes adopted by authors in their accounts for the above two species, i.e. Ohwi (1933, 1935), Keng (1959), Hsui (1971), Liu (1987). Zhao (1995) reestablished the genus Aniselytron in the Chinese flora, widened its circumscription, and recognized seven species and two varieties. Currently, Aniselytron clemensae (Hitchc.) Soják and Aniselytron pseudopoa (Jansen) Soják are placed in synonymy of Aniselytron treutleri (Korthof and Veldkamp, 1984); Aniselytron epileuca (Stapf) Soják was moved to the genus Poa, as Poa epileuca (Stapf) Stapf (Veldkamp, 1994); Aniselytron gracilis (Keng) N.X. Zhao and Aniselytron petelotii (Hitchc.) Soják were synonymysed with Deyeuxia abnormis Hook. f. emend. Paszko (Korthof and Veldkamp, 1984; Paszko and Soreng, 2013; Paszko et al., 2017). Ma, Peng, and Li (2005) discovered that there are sharp differences between Aniselytron and Calamagrostis based on their leaf anatomy and provided valuable support that Aniselytron should be generically separated from Calamagrostis. Recently, Gillespie et al. (2008) recognized Aniselytron as accepted genus originated by ancient hybridization.

Aniselytron treutleri differs from Aniselytron agrostoides by its longer lower glumes $(0.5-2.5 \mathrm{~mm}$ vs. absent or up to $0.75 \mathrm{~mm}$ long), number of veins on lower glumes 
(1-veined vs. veinless), number of veins on upper glumes (3-veined vs. 1-veined), and wider leaf blades (5-15 $\mathrm{mm}$ vs. 3-6 mm wide) (Korthof and Veldkamp, 1984; Hsu et al., 2000; Lu and Phillips, 2006).

Examined specimens (new records)

China: Hunan Prov., Xinning Co., Mt. Ziyun, $1250 \mathrm{~m}$ a.s.l., 8 September 1984, Ziyun Mt. Team 881 (PE); Xinning Co., Wanfeng, 13 May 1985, Y.B. Luo 2340 (PE); Xinning Co., Wanfeng, 14 May 1985, Y.B. Luo 2393 (PE); Xinning Co., Huangmuqiao, under the bamboo forest, $800 \mathrm{~m}$ a.s.l., 9 July, Y.B. Luo 2549 (PE). Jiangxi Prov., Anfu Co., Mt. Wugong, 1250 m a.s.l., August 1963, J.S. Yue 3625 (PE).

\section{Atraphaxis karataviensis Pavlov \& Lipschitz (Polygonaceae)}

Contributors - Arkadiusz Nowak, Marcin Nobis

Distribution and habitat

Atraphaxis karataviensis is an endemic species to the Karatu Mts., the westernmost range of the Tian-Shan (the Syrdarian subsection) and northwestern Pamir-Alai within Kyrgyzstan in Middle Asia (Pavlov, 1936). It is known from the few stations on screes and rock outcrops in desert-like, dry habitats in mid elevation zones, mainly between 1300-2000 m a.s.l. (Pavlov, 1936; Ovchinnikov, 1968). The species was supposed to occur in Tajikistan and mentioned in the 3rd volume of the country's flora (Ovchinnikov, 1968). During the field research in the northern Pamir-Alai (Tajikistan), we found a population of Atraphaxis karataviensis on rock faces in the Alaian range north from Damburacha settlement. Population including approximately 200 individuals composes a dwarf-shrub stand on southern exposition, on limestone outcrops. Also Silene guntensis, Campanula lehmanniana and Asperulula albiflora contribute to the plant community. The location is one of the highest of this species, elevated up to $3000 \mathrm{~m}$ a.s.l.

Taxonomic notes

Until now, five species of the genus Atraphaxis were reported from Tajikistan. The differences between species concern mainly flower structure and leaves position (Ovchinnikov, 1968). Atraphaxis karataviensis (Figure 1) can be easily distinguished from other Atraphaxis species by its 4-petal flowers and dwarf-shrub life form $(10-30 \mathrm{~cm}$ tall). Additionally, Atraphaxis karataviensis has small leaves (ca. 2-3 mm long) whereas most similar Atraphaxis spinosa L. has longer leaves (up to $9 \mathrm{~mm}$ ) and is a much higher plant (30-90 cm tall).

Examined specimens (new records) Tajikistan: Alaian Range: near Damburacha settlement, dwarfshrub rupiculous community dominated by Atraphaxis karataviensis; $39^{\circ} 16^{\prime} 23.7^{\prime \prime} \mathrm{N} / 71^{\circ} 20^{\prime} 28^{\prime \prime} \mathrm{E}$, alt. $2951 \mathrm{~m}$, 3 June 2015, A. Nowak \& M. Nobis (OPUN).

\section{Hackelochloa granularis (L.) Kuntze (Poaceae)}

Synonyms: Cenchrus granularis L., Manisuris granularis (L.) L. f., Mnesithea granularis (L.) de Koning and Sosef, Rottboellia granularis (L.) Roberty.
Contributor - Beata Paszko

Distribution and habitat

Hackelochloa granularis (Linnaeus) Kuntze has a more or less pantropical distribution. In China, $H$. granularis was recorded till now from the following provinces: Anhui, Fujian, Guangdong, Guangxi, Guizhou, Hainan, Sichuan, Taiwan, Yunnan, and Zhejiang (Sun and Phillips, 2006). Here, the first records of $H$. granularis are reported from Hunan (Baojing, Dongkou, and Yizhang Counties) and Jiangxi (Dexing City and Tonggu County), Southeast China. Hackelochloa granularis occur in tropical, subtropical and warm temperate zones of the world. It grows on grassy slopes, in forest gaps and in disturbed areas, at elevation between 100 and $1000 \mathrm{~m}$ a.s.l. (Noltie, 2000; Sun and Phillips, 2006).

\section{Taxonomic notes}

Hackelochloa (Poaceae: Andropogoneae) is a genus including only two species: Hackelochloa granularis (Linnaeus) Kuntze and Hackelochloa porifera (Hackel) D. Rhind. Both of them are recorded in China. This genus is readily recognizable by its unique, globose or broadly oblong, sessile spikelets. The status of the genus itself and the species distinction itself have been questioned. Veldkamp, de Koning, and Sosef (1986), Veldkamp et al. (2013) and their followers, i.e. Soreng et al. (2015) placed its two members in the related genus Mnesithea Kunth, and Hackelochloa porifera has subsequently been treated as a synonym of Mnesithea granularis (L.) de Koning and Sosef. Recently, Arthan et al. (2016) supported the recognition of Hackelochloa porifera as distinct from Hackelochloa granularis and provided evidence that the genus Hackelochloa should be maintained. Hackelochloa granularis differs from Hackelochloa porifera in spikelet morphology. Both species differ in shape of sessile spikelet (subglobose in Hackelochloa granularis vs. broadly oblong in Hackelochloa porifera), structure of lower glume surface (pitted and tubercled on the back in Hackelochloa granularis vs. ridged and reticulate on the back in Hackelochloa porifera), lower glume length of sessile spikelet (0.8-1.3 mm long in Hackelochloa granularis vs. 1.5-2.5 mm long in Hackelochloa porifera), and length of racemes (up to $1.5 \mathrm{~cm}$ in Hackelochloa granularis vs. more than $2 \mathrm{~cm}$ in Hackelochloa porifera) (Noltie, 2000; Sun and Phillips, 2006; Arthan et al., 2016).

Examined specimens (new records)

China: Hunan Prov., Baojing Co., Qiapeng, $500 \mathrm{~m}$ a.s.l., 11 September 1958, L.H. Liu 9759 (PE); Dongkou Co., Mt. Xuefeng, 1954, W. Li s.n. (PE); Yizhang Co. Mt. Mangshan, 550 m a.s.l., 24 August 2005, B.Z. Xiao 4593 (PE). Jiangxi Prov., Dexing City, 9 October 1958, M.X. Nie 5561 (PE); Tonggu Co., 300 m a.s.l., 25 September 1963, S.K. Lai $3774(\mathrm{PE})$. 


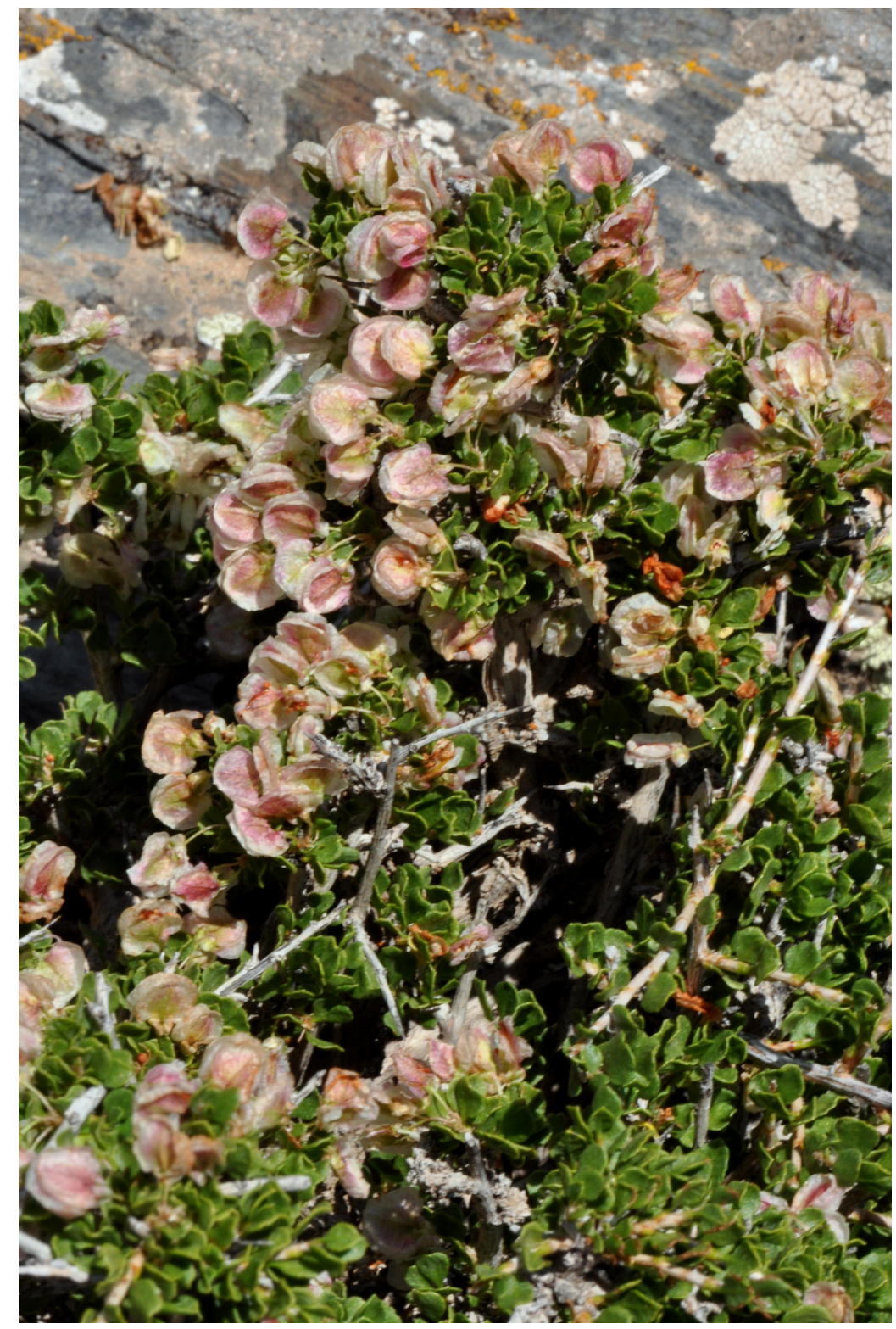

Figure 1. Atraphaxis karataviensis Pavlov \& Lipschitz near Damburacha settlement in Tajikistan, June 2015, phot. A. Nowak.

\author{
Megadenia speluncarum Vorob., Vorosch. \& Gorovoj \\ (Brassicaceae) \\ Contributors - Marina V. Olonova, Robert J. Soreng \\ Distribution and habitat \\ Megadenia speluncarum was described (Vorobyev et \\ al., 1976) from the samples collected near a calcareous cave \\ in the Lozovoy mountain range (Chandalaz) in southern \\ Primorsky Krai (Russian Far East). As a rare plant and \\ narrow endemic M. speluncarum is under protection in \\ Russia (Malyshev, 2008). \\ A joint botanical expedition of Tomsk State University \\ and Smithsonian Institution encountered a new population
}

of Megadenia speluncarum about $300 \mathrm{~km}$ from its locus classicus, in the forest on the Vityaz Bay, near the road, in 2018. The population covered an area of about $4.5 \mathrm{~m}^{2}$. It included vegetative as well as reproductive individuals (Figure 2). More localities of this rare species are likely to be found near the newly reported location.

Taxonomic notes

Previously, the genus Megadenia Maxim. includes three species. They are distributed on the QinghaiTibetan Plateau (Megadenia pygmaea Maxim.), in eastern Sayan Mts south of Lake Baikal (Megadenia bardunovii Popov), and Primorsky Krai, Lozovoy Ridge (Megadenia 


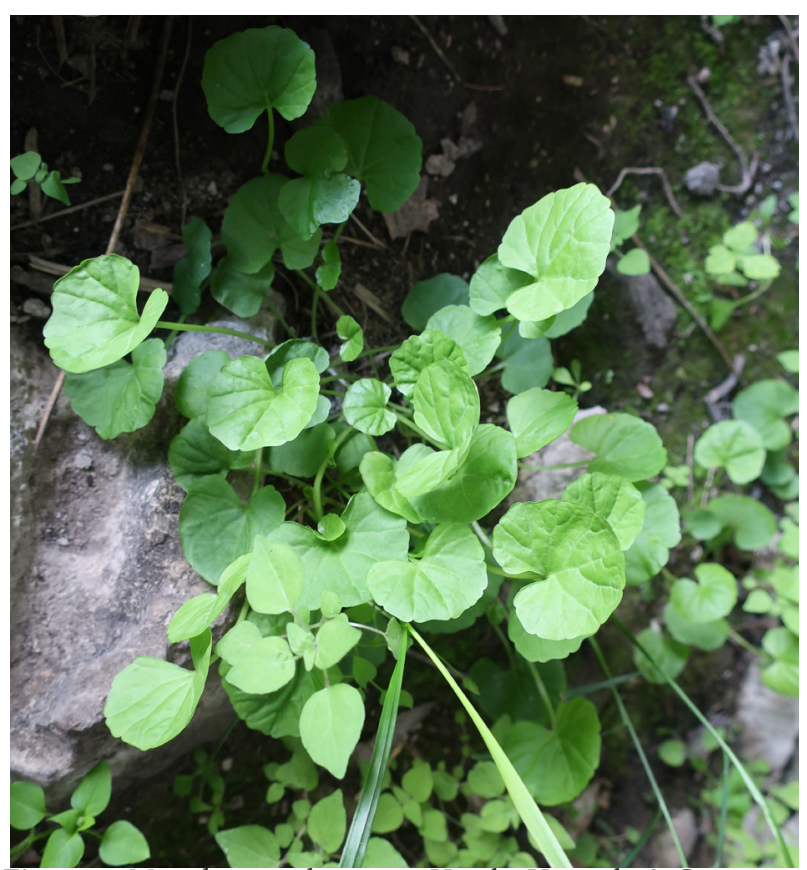

Figure 2. Megadenia speluncarum Vorob., Vorosch. \& Gorovoj at the Vitiaz' bay (Russian Far East, Primorskiy kray) aside the road between Alexeevka and Vitiaz', in shedy broad-leafed forest, near the brook, June 2018, phot. M. Olonova.

speluncarum). Later the taxonomic status of these species was evaluated, and all three species, due their high morphological similarity, were synonymized as Megadenia pygmaea (Berkutenko, 1998; Zhou et al., 2001; Ostroumova and Berkutenko, 2010). Finally, detailed research, using molecular methods, allowed Artyukova, Kozyrenko, and Gorovoy (2014) to restore the species status for Megadenia speluncarum. Their data on the plastid genome revealed a clear subdivision of the genus into three lineages matching the three described species.

\section{Examined specimens (new record)}

Russia:Primorskiy Krai, KhasanskiyDistrict, VityazBay, along the road between settlements Vityaz and Alekseevka, near the brook in shady Betula - Quercus forest. 27 Jun 2018, R.J. Soreng \& M.V. Olonova (TK-004029).

\section{Melica kozlovii Tzvelev (Poaceae)}

\section{Contributor - Beata Paszko}

\section{Distribution and habitat}

According to $\mathrm{Wu}$ and Phillips (2006) Melica kozlovii occurs in central Asia, in China and Mongolia. Till now, the species was recorded from the following Chinese provinces: Gansu, Qinghai, and Shanxi. Tzvelev (1968) described M. kozlovii based on two different collection events. Tzvelev (1968) cited as type the V.F. Ladygin's collection no. 367 gathered during the Tibet Expedition (1899-1901) leaded by Pyotr K. Kozlov (Andreev and Yusopova, 2015). The type locality is located in the vicinity of Dulan-Chit (Dulankit Gompa, ca. $15 \mathrm{~km}$ NE of Wulan, Wulan Co., northeastern margin of Quaidam Basin) in Qinghai, China (Tzvelev 1968). Tzvelev cited also, M.I. Petrov's collection gathered $15 \mathrm{~km} \mathrm{~N}$ of Yongchang (Russian: Юнча́н) (Yongchang Co., Gansu, China) on 28 June 1958. This second locality was probably erroneously assigned to Mongolia by Wu and Phillips (2006) in the Flora of China. The second locality is prescribed by Tzvelev (1968) to the Mongolica Province, the Mongolia Subprovince, and the Chesi Region. These regions were defined by Grubov (1963) and the area of Mongolia Subprovince sensu Tzvelev (1968) does not correspond with the present borders of Mongolia. The Chesi region is located mostly in the present-day area of Gansu, what was shown on the map provided by Grubov (1963). Later, Grubov (1982) as well as Hempel (2011) did not listed $M$. kozlovii for Mongolia. Here, new record of M. kozlovii is reported from Helan Mountains at the Alxa Left Banner in the southwest Inner Mongolia, China. Wu and Phillips (2006) and Huang et al. (2011) provided eight Chinese endemic species in the genus Melica. Melica kozlovii was not listed by these authors. My findings showed that the distribution range of $M$. kozlovii is restricted to China, and this species should be recognized as a Chinese endemic. Melica kozlovii occurs in the middle and upper mountain areas, at rocky slopes and in mountain valleys, from 1950 $\mathrm{m}$ to $3900 \mathrm{~m}$.

\section{Taxonomic notes}

The genus Melica is represented by 23 species in China (Wu and Phillips, 2006). Melica kozlovii belongs to the group consisting of several species characterized by branched panicles bearing more than 15 spikelets per panicle branch. Melica kozlovii differs from Melica tangutorum Tzvelev, Melica tibetica Roshevitz, and Melica subflava Z. L. Wu by the laxer panicles, presence of lobes, ca. $3 \mathrm{~mm}$ wide, at the junction of leaf sheath and blade, and longer anthers, 1.2-2.2 $\mathrm{mm}$ long ( $\mathrm{Wu}$ and Phillips, 2006). According to Hempel (2011) Melica kozlovii together with Melica secunda Regel, Melica tangutorum, Melica tibetica, and Melica subflava are members of section Melicella Camus ex W. Hempel, subsection Schizolemma (Z. L. Wu) W. Hempel.

\section{Examined specimens (new records)}

China: Inner Mongolia, Alxa League, Alxa Left Banner,

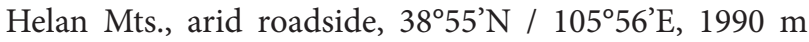
a.s.l., 8 June 2008, W.J. Yang \& C.F. Zhang 080608122 (PE).

\section{Melica nutans L. (Poaceae)}

Contributor - Beata Paszko

Distribution and habitat

Melica nutans is a widespread Eurasian woodland species. It is distributed in most of Europe, but it is rare in the Mediterranean region and its islands. In Asia, it occurs in Siberia, Soviet Far East, Soviet Middle Asia, the 
Caucasus, northern China, and eastern Asia (Meusel et al., 1965; Tutin, 1980; Tyler, 2002). Melica nutans is quite rare in China. Till now, it was recorded from Heilongjiang and Xinjiang provinces (Wu and Phillips, 2006). Here, new records of $M$. nutans are reported from Changbai Mt. in the Antu County in the southern Jilin and in the Ningwu County of Shanxi, China. Melica nutans is a rhizomatous, perennial grass occurring in shady and often rocky places in deciduous woodland, and on woodland margins.

\section{Taxonomic notes}

There are three Melica species (Melica grandiflora Koidz., Melica nutans, Melica pappiana W.Hempel) that are characterized by racemelike panicles, bearing a few (3-15) spikelets. Melica nutans differs from Melica grandiflora and Melica pappiana by shorter spikelets, (5-8 mm long vs. 7-10 $\mathrm{mm}$ long, respectively), purplish red glumes (vs. glumes usually green), eventually nodding panicles (vs. erect panicles) (Wu and Phillips, 2006).

Examined specimens (new records)

China: Jilin-Antu Co., N slope of Mt. Changbai, forest edge, 1500 m a.s.l., 2 August 1957, J.Y. Qian et al. 620 (PE); Antu Co., Mt. Changbai, coniferous forest, $1750 \mathrm{~m}$ a.s.l., 3 August 1963, W.L. Wang et al. 2434 (PE). Shanxi - Ningwu Co., $\mathrm{S}$ of Majiazhuang village, pine forest, $2100 \mathrm{~m}$ a.s.l., 26 July 1957, J.M. Liu 1879 (PE).

Petrorhagia prolifera (L.) P.W.Ball \& Heywood (Caryophyllaceae)

Synonyms: Dianthus prolifer L., Kohlrauschia prolifera

(L.) Kunth, Tunica prolifera (L.) Scop.

Contributors - Agnieszka Nobis, Marcin Nobis, Arkadiusz Nowak, Georgy A. Lazkov

Distribution and habitat

Natural range of Petrorhagia prolifera includes central and southern Europe as well as southwest Asia (region between the Black Sea and the Caspian Sea) (Ball and Akeroyd, 2010). Besides, the species was introduced to Africa, North and South America and Australia (Global Biodiversity Information Facility 2019). In the mountains of central Asia the genus Petrorhagia has been represented only by Petrorhagia alpina (Habl.) P.W.Ball \& Heywood (Bondarenko, 1971; Lazkov and Sultanova, 2014) and Petrorhagia cretica (L.) P.W.Ball \& Heywood, the latter restricted to Turkmenistan (Kopetdag) (Bondarenko, 1971). Petrorhagia prolifera was recorded for the first time in central Asia in 2015. The occurrence of the species was confirmed in the next year. Population of the species was observed on the roadside in Kyrgyzstan (Figure 3), and it included several hundreds of individuals. Probably, Petrorhagia prolifera has been accidentally introduced in this region and further localities will be found in near future.

\section{Taxonomic notes}

The genus Petrorhagia (Ser. ex DC.) Link includes ca. 20 species distributed mainly in the Mediterranean

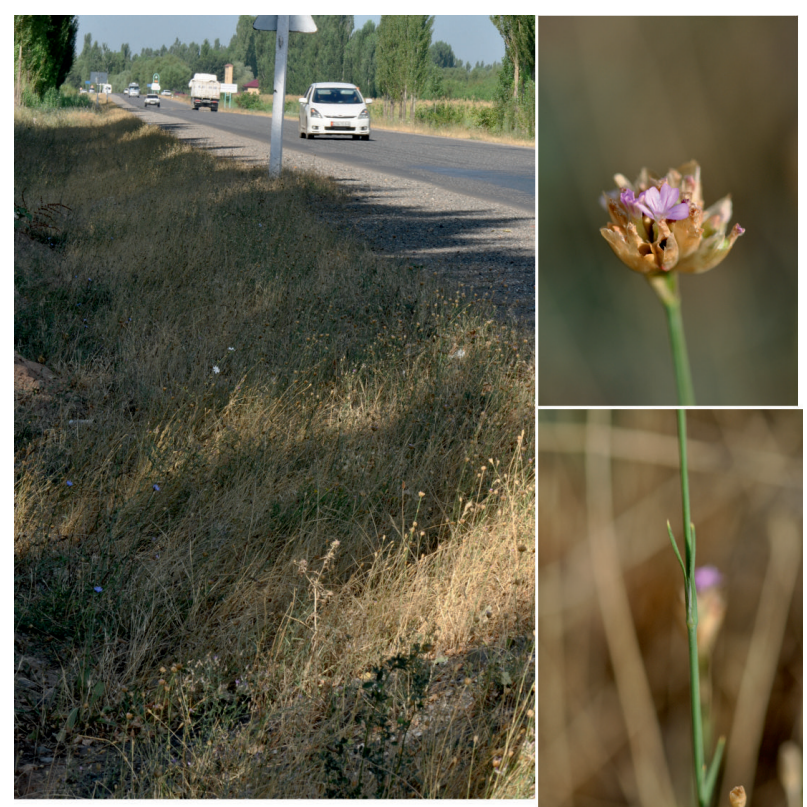

Figure 3. Petrorhagia prolifera (L.) P.W.Ball \& Heywood, roadside, ca. $6 \mathrm{~km}$ S of Jalalabad in Kyrgyzstan, July 2016, phot. M. Nobis.

region. All species are typical for dry, calcareous or sandy habitats (Ball and Akeroyd, 2010). Petrorhagia prolifera can be easily distinguished from Petrorhagia alpina and Petrorhagia cretica which are annual plants with white petals (3-9 $\mathrm{mm}$ long in Petrorhagia alpina and included in the calyx in Petrorhagia cretica) whereas Petrorhagia prolifera is perennial and has pink petals with darker veins (10-14 mm long).

\section{Examined specimen (new record)}

Kyrgyzstan: Fergana valley, roadside, ca. $6 \mathrm{~km} \mathrm{~S}$ of Jalalabad, $40^{\circ} 51^{\prime} 39^{\prime \prime} \mathrm{N} / 73^{\circ} 01^{\prime} 05^{\prime} \mathrm{E}, 739 \mathrm{~m}$ a.s.1., 23 July 2016, M. Nobis \& A. Nobis (KRA 0494223).

\section{Puccinellia schischkinii Tzvelev (Poaceae)}

Contributors - Anna Wróbel, Marcin Nobis, Ewelina Klichowska, Arkadiusz Nowak

\section{Distribution and habitat}

According to Tzvelev (Tzvelev, 1976) and Liang and Tzvelev (2006) the overall range of Puccinellia schischkinii extends from Siberia to Mongolia and central Asia, where it grows on saline soils within grasslands, meadows and marshes. The species' distribution, however, is still not well recognized and requires further field research. Although the occurrence of $P$. schischkinii was suggested from Kyrgyzstan and Tajikistan by some authors (Liang and Tzvelev, 2006), the species has not been listed in the flora of these countries (Ovchinnikov, 1957; Lazkov and Sultanova, 2014). In Middle Asia P. schischkinii has been confirmed only in Kazakhstan (Kamelin, 1998).

A population of Puccinellia schischkinii was discovered near the road A365 in the vicinity of At-Bashy (Naryn 
Region, Kyrgyzstan) during expedition to Tian-Shan Mountains in 2018 (Figure 4). This is the first record of this species to Kyrgyzstan. At the locality, more than 100 individuals of $P$. schischkinii grew between roadside and small watercourse, on clay alkaline soil characterized by high concentration of salts $(23050 \mu \mathrm{S} / \mathrm{cm})$.

\section{Taxonomic notes}

Puccinellia schischkinii is a perennial diploid species $(2 \mathrm{n}=14)$ (Probatova et al., 2013) belonging to the section Puccinellia (Tzvelev, 1976). As still little is known about evolutionary history of Puccinellia in Middle Asia, further integrative studies are needed to shed more light on the phylogenetic relationship among taxa in the genus and refine their taxonomic classification (Wróbel et al. in prep.).

Useful morphological characters for Puccinellia schischkinii identification are: culm $15-55 \mathrm{~cm}$ long with short vegetative shoots near the base; lower leaf sheaths greyish-green; panicle up to $20 \mathrm{~cm}$ long, usually more than $1 / 3$ of the culm length (length of a culm without panicle length), dense and contracted, rarely slightly open, scabrous; pedicels of lateral spikelets very short, up to 1 $(-1.5) \mathrm{mm}$ long; spikelets with up to 7 flowers, slender, ca. $1.5 \mathrm{~mm}$ wide, adhering tightly to primary branches; lemma of the lowest floret in spikelet ovate, slightly pilose at the base, with obtuse triangular apex, light green, usually with violet tinge in upper half and golden edge at the apex, 2.5-3 mm long; palea with numerous spinules in upper $1 / 2-2 / 3$ of its length; anthers $0.8-1.2 \mathrm{~mm}$ long.
Puccinellia schischkinii can be confused with Puccinellia roshevitsiana (Schischk.) V.I.Krecz. ex Tzvelev but the latter taxon has shorter and more lax panicle which is up to $1 / 4$ of the culm length (length of a culm without panicle length), longer anthers $1.6-2.5 \mathrm{~mm}$ long and slightly longer lemma 2.7-3.5 mm long (Tzvelev, 1976).

Examined specimens (new record)

Kyrgyzstan: Tian-Shan Mountains, Naryn Region, ca. $6.5 \mathrm{~km} \mathrm{NNW}$ of At-Bashy, ca. $36 \mathrm{~km} \mathrm{SW}$ of Naryn, (right roadside towards At-Bashy), saline site, 6 July 2018, M. Nobis, E. Klichowska, A. Wróbel \& A. Nowak (KRA 0488781-0488783, 0488785, 0488787-0488792, 04888030488806, 0488809).

Solanum physalifolium Rusby var. nitidibaccatum (Bitter) Edmonds (Solanaceae)

Contributors - Nikita A. Vershinin, Igor V. Kuzmin

Distribution and habitat

Solanum physalifolium is a species native to the Andes (Argentina, Bolivia and Chile). It is adventive and naturalized in Europe, western Canada, the northwestern United States, equatorial regions of Africa, and it has been introduced into Australia and New Zealand where it persists as a weed of cultivation (Edmonds, 1986; Edmonds and Chweya, 1997). The species grows in ruderal habitats, on railways embankments, in fields and disturbed areas. In Russia, it was collected in Kursk, Moscow, Ryazan Oblasts, the Republic of Mordovia (Mayorov, 2014), Udmurt Republic (Melnikov, 2011), however, it has not been encountered in the eastern regions of the country.

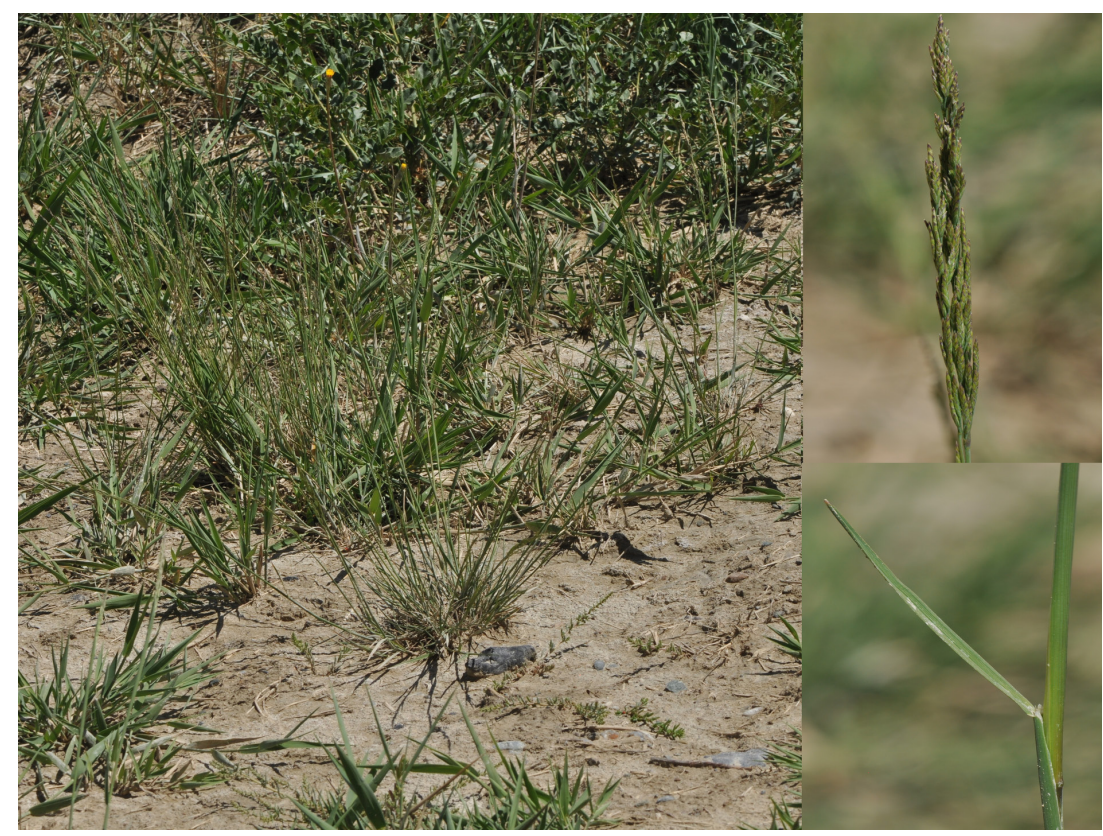

Figure 4. Puccinellia schischkinii Tzvelev, near At-Bashy in Kyrgyzstan, July 2018, phot. M. Nobis. 
We found a few new locations of the species on the potato field and on the roadsides, ca. $700 \mathrm{~km}$ eastwards of the previously known localities. Potato fields were also the habitat of this species in other Russian regions. Solanum physalifolium var. nitidibaccatum is a new alien established species to the flora of Siberia and Asian Russia.

\section{Taxonomic notes}

Solanum physalifolium belongs to sect. Solanum, which includes about 15 species of Solanum nigrum complex. Two varieties of Solanum physalifolium species have been recognized: var. physalifolium (which has a restricted South American distribution) and var. nitidibaccatum (synonyms: Solanum nitidibaccatum Bitter; Solanum sarrachoides Sendtn. pro parte), which successfully spreads beyond South America (Edmonds, 1986). Plants from the Tyumen region have 4-8-flowered inflorescences, broadly triangular sepals, and broadly ovoid berries with two sclerotic granules. On this basis they can be recognized as representing Solanum physalifolium var. nitidibaccatum.

Examined specimens (new records)

Russia: Tyumen Oblast, Tyumen District, $20,5 \mathrm{~km}$ to the West of Tyumen, near Uspenka, $57^{\circ} 05^{\prime} 31.7^{\prime \prime} \mathrm{N} /$ $65^{\circ} 06^{\prime} 55.4^{\prime \prime} \mathrm{E}$, potato field, 30 July 2016, N. Vershinin s.n. (Univ. of Tyumen); Tyumen Oblast, Tyumen District, 20 $\mathrm{km}$ to the West of Tyumen, near highway YekaterinburgTyumen, $57^{\circ} 05^{\prime} 32.6^{\prime \prime} \mathrm{N} / 65^{\circ} 07^{\prime} 25.2^{\prime \prime} \mathrm{E}$, potato field, 1 August 2017, I. Kuzmin \& N. Vershinin s.n. (MW, NS); Tyumen Oblast, Tyumen District, $20.5 \mathrm{~km}$ to the West of Tyumen, near Uspenka, $57^{\circ} 05^{\prime} 32.1^{\prime \prime} \mathrm{N} / 65^{\circ} 07^{\prime} 09.9^{\prime \prime} \mathrm{E}$, potato field, 26 August 2017, N. Vershinin s.n. (Univ. of Tyumen); Tyumen Oblast, Tyumen District, $20 \mathrm{~km}$ to the West of Tyumen, near highway Yekaterinburg-Tyumen, $57^{\circ} 05^{\prime} 32.5^{\prime \prime} \mathrm{N}$ / 6507'18.1”E, 17 September 2017, I. Kuzmin s.n. (LE, Univ. of Tyumen), 10 August 2018 obs. N. Vershinin.

\section{Stipa pulcherrima K.Koch (Poaceae)}

Synonyms: Stipa grafiana Steven, Stipa pennata L. subsp. pulcherrima (K.Koch) Á.Löve \& D.Löve, Stipa pennata L. subsp. pulcherrima (K.Koch) Freitag, Stipa glabglabrinoda Klokov, Stipa pulcherrima subsp. glabrinoda (Klokov) Tzvelev, Stipa heterophylla Klokov, Stipa pulcherrima var. karadagensis Tzvelev, Stipa pulcherrima subsp. palatina H.Scholz \& Korneck.

Contributors - Ewelina Klichowska, Marcin Nobis, Anna Wróbel, Arkadiusz Nowak

\section{Distribution and habitat}

Stipa L. is one of the largest genera in the family Poaceae, subfamily Pooideae (Soreng et al., 2015), which in the narrow approach comprises over 150 species distributed in open habitats (grasslands, steppes, meadow steppes or forest steppes) of the Old World. Stipa pulcherrima K. Koch is a widely distributed Eurasian species. Its range extends from Siberia, through the southern Ural, the Black Sea, the
Caucasus, and the Mediterranean area to central Europe, where the species reaches the northwestern limit of its geographic range (Martinovský, 1980). Here, we report a new record of S. pulcherrima from central Tian-Shan Mts in Kyrgyzstan, where it grows in steppe community on steep, sunny slope of the river valley, with north exposition (Figure 5). The new locality is the easternmost known location of the taxon. Stipa pulcherrima is a new native species to Kyrgyzstan.

\section{Taxonomic notes}

Stipa pulcherrima belongs to the section Stipa, and is characterized by having dorsal line of hairs fussed with subdorsals and ventral line of hairs always reaching the base of the awn, leaves of the vegetative shoots $0.7-1.4$ $\mathrm{mm}$ in diameter, their adaxial (upper) surface covered by short, up to $0.08 \mathrm{~mm}$ prickles and short hairs (up to $0.15-0.3 \mathrm{~mm}$ long) present only on the sides of the ribes (Nobis et al., 2017), whereas abaxial (lower) surface is more or less scabrous due to hard hooks and short prickles. In Kyrgyzstan this species could be confused with Stipa zalesskii Wilensky (belonging to Stipa dasyphylla (Lindem.) Trautv. group), which differs from Stipa pulcherrima by having ventral line of hairs terminating at the distance of $0.3-1 \mathrm{~mm}$ below the top of the lemma, leaves of the vegetative shoots $0.3-0.8 \mathrm{~mm}$ in diameter, their abaxial surface scabrous due to mixture of prickles, spinules and hairs, whereas adaxial covered with mixture of short and long hairs (Nobis et al., 2019).

Examined specimens (new record)

Kyrgyzstan: Central Tian-Shan, ca. $36.5 \mathrm{~km}$ NNE of Naryn, ca. $63 \mathrm{~km} \mathrm{NE}$ of At-Bashy, steppe on slope/shrubs, $41^{\circ} 29^{\prime} 41^{\prime \prime} \mathrm{N} / 76^{\circ} 25^{\prime} 33^{\prime \prime}$ E, $2283 \mathrm{~m}$ a.s.l., exp. N, incl. $25^{\circ}$, 6 July 2018, M. Nobis, E. Klichowska, A. Wróbel, A. Nowak (KRA 0502537, 0502538, 0502540, 0502541，0502542, 0502544).

\section{Thymus lenensis Vasjukov (Lamiaceae)}

Contributors - Vladimir M. Vasjukov, Denis A. Krivenko, Irina N. Egorova

\section{Distribution and habitat}

Thymus lenensis is an endemic plant species occurring along sandy-pebble river banks of the Lena River Basin, previously known from North-Eastern Siberia (in the central part of Yakutia) and only from the type specimens collected in 1962 (paratype: "Yakutia, Kobyayskiy District, right bank of the Lena River, $8 \mathrm{~km}$ from the Smorodichnogo, Solenaya duct, pebbles, 7 Aug 1962, E. R. Trufanova, № 100/1” - LE 01017945, s. n. TK) and 1970 (holotype: "Yakutia, Kobyayskiy District, right bank of the Lena River opposite to the mouth of the Vilyui River, pebbles on the bank of the Lena near the village Kitchan, 13 Aug 1970, E. R. Trufanova, № 44/2" - MW 0128679) (Vasjukov, 2016). 


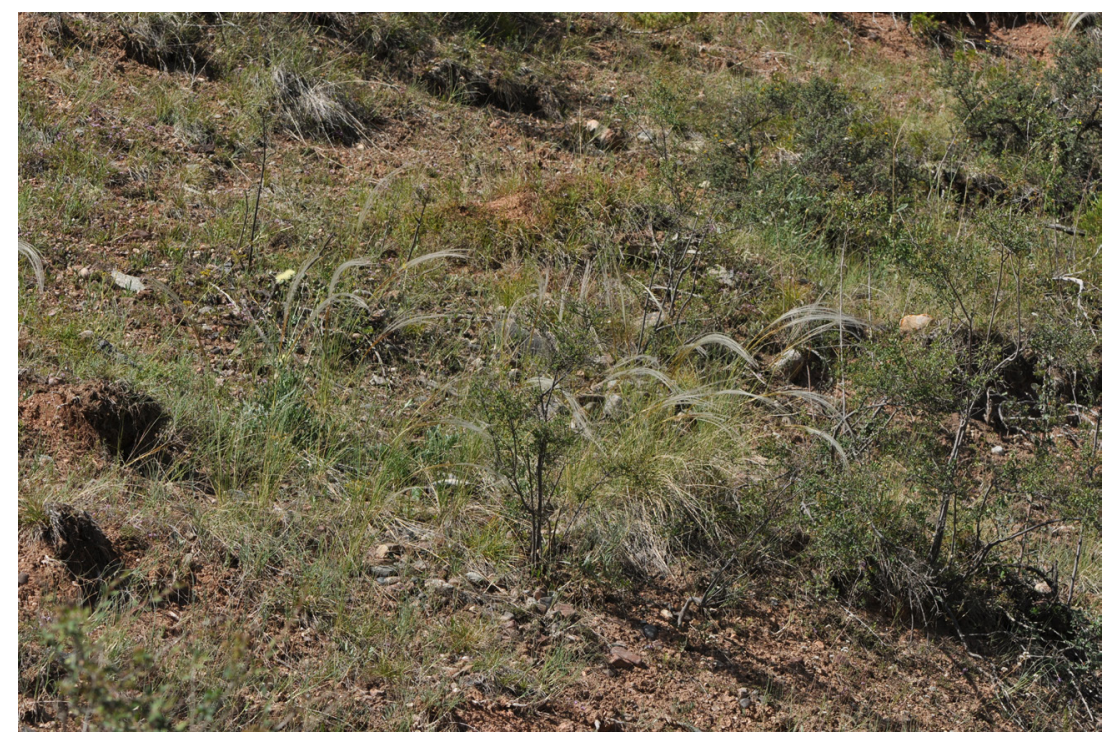

Figure 5. Stipa pulcherrima K. Koch, ca. 36.5 km NNE of Naryn in Kyrgyzstan, July 2018, phot. M. Nobis.

The revision of Thymus L. in the IRK herbarium (Irkutsk, Russia) resulted in finding specimens collected from Irkutsk Oblast and representing Thymus lenensis, providing the first record of this species from the southern part of Siberia.

\section{Taxonomic notes}

Thymus lenensis is a dwarf semishrub with short stalks (1-2 mm thick) ending in a generative shoot. Generative shoots erect, $7-15 \mathrm{~cm}$ high, roundish, densely pubescent with squarrose and rather short hairs under inflorescence, as well as on vegetative shoots. Cauline leaves oblong to elliptic and roundish, 6-12 $\mathrm{mm}$ long and (2-)3-7 $\mathrm{mm}$ wide, petiolate, with distinct veins beneath; hispidulous above and sometimes beneath; viscid glands well distinct. Inflorescence branched. Flowering calyx purple, 3.5-4 $\mathrm{mm}$ long; teeth of upper lip ciliate. Corolla 5-6 $\mathrm{mm}$ long, purple.

Thymus lenensis is closely related to Thymus sergievskajae Karav. Both species belong to the section Verticillati (Klokov et Des.-Shost.) Klokov. Thymus sergievskajae differs from Thymus lenensis by the shoots pubescent throughout with horizontally oriented long hairs ca. 1-1.2 mm long, cauline leaves 3-10 $\mathrm{mm}$ long and $2.5-4(-5) \mathrm{mm}$ wide, hairy on both surfaces or glabrous above.

\section{Examined specimens (new records)}

Russia: Irkutsk Oblast, Kazachinsko-Lenskiy District, left bank of the Kirenga River-right tributary of the Lena River, vicinity of Ermaki village, meadow, alt. $370 \mathrm{~m}$, $56^{\circ} 37^{\prime} 52^{\prime \prime} \mathrm{N} / 107^{\circ} 46^{\prime} 57^{\prime \prime} \mathrm{E}, 19 \mathrm{Jul} 2010$, I. N. Egorova 51380 (IRK).
New records for Europaean countries

Dichondra micrantha Urb. (Convolvulaceae)

Contributors - Gergely Király

Distribution and habitat

Dichondra micrantha is native to tropical and warmtemperate regions, with controversial reports on the precise range: some authors, e.g. Tharp and Johnston (1961), Correll and Correll (1982), Fang and Staples (1995), consider it to be native in both hemispheres, others restrict its native range to entral America (Silvestre, 2012), or to east Asia (Clement and Foster, 1994). In Europe, it is a cultivated plant used as a ground-cover plant or grasssubstitute in lawns, and usually is treated as casual alien tending to establish only in regions of mild winter climate, e.g. Great Britain, Iberian Peninsula, Italy, and the Balkans (Euro+Med Plantbase, 2018). The closest populations to Hungary were observed in villages along the Adriatic Coast (Milović and Mitić, 2012; Tafra et al., 2013; Barina et al., 2015), and in northern Italy (Selvaggi et al., 2013).

The newly discovered locality of Dichondra micrantha is situated in southwestern Hungary, in the town centre of Kaposvár, where clones larger than $1 \mathrm{~m}$ in diameter were found in lawns, and in the cracks of pavements. Based on the extension of the clones they are multiannual, and could survive the winters here obviously due to the urban heat effect. The plants were observed on 18 January 2019 after a long cold period, and, especially in sheltered position, they were completely fresh and green.

\section{Taxonomic notes}

The genus Dichondra J. R Forst \& G. Forst. includes creeping or sprawling perennial herbs with alternate, 
long-petioled reniform leaves. In the subgenus Dichondra (where D. micrantha is placed), the fruits are deeply bilobed, and the carpels usually one-seeded. Dichondra micrantha has thin stolons $(<1 \mathrm{~mm}$ in diameter), leaves sparsely pubescent with appressed hairs, a corolla about as long as calyx at anthesis, and calyx-lobes twice as long as broad or less, shorter than the fruits (Tharp and Johnston, 1961; Correll and Correll, 1982; Silvestre, 2012). Dichondra micrantha is the only species of the genus with reliable records in Europe, other species probably have been reported erroneously (Clement and Foster, 1994; Otto and Verloove, 2016).

\section{Examined specimen (new record)}

Hungary: Somogy County, Kaposvár, Talián Gy. Street, in the cracks of the pavement and on the base of house walls, $152 \mathrm{~m}$ a.s.l., $46.36246^{\circ} \mathrm{N} / 17.79729^{\circ} \mathrm{E}, 18$ January 2019, G. Király (BP 00013799).

Orobanche serbica Beck \& Petrović (Orobanchaceae) Synonyms: Orobanche ozanonis F.W. Schultz ex Beck. Contributors - Óscar Sánchez Pedraja, Renata Piwowarczyk, Gonzalo Moreno Moral

\section{Distribution and habitat}

Orobanche serbica is an exclusive parasite of Artemisia alba Turra (=Artemisia camphorata Vill). The species is known from few isolated localities situated in Bulgaria, Albania, Serbia, France and Spain, where it grows in mountainous areas, especially on rocky, calcareous and sunny slopes. New locality of Orobanche serbica has been found in Parma Province in Italy. The species is a new, native taxon to the flora of this country.

\section{Taxonomic notes}

Orobanche serbica was described from Serbia by Beck \& Petrović in Petrović (1885) based on a plant material collected by Sava Petrović: "monte Visa supra monast. sv. Bogorodice", parasitizing Artemisia camphorata. Previously, under the name of Orobanche ozanonis had been distributed by F.W. Schultz through his exsiccata ("F. Schultz, herbarium normale. Cent. 10. [exc. n.] 924 ... 10 July 1859") made on the basis of a French gathering of Charles Ozanon: "Sur l'Artemisia camphorata dans les détritus des rochers schisteux des Portes, à $2000 \mathrm{~m}$, près de Lagrave (Hautes-Alpes)"; the name of Schultz's exssicata was later published correctly by Beck (1890). According to Carlón et al. (2008), Orobanche serbica and Orobanche ozanonis are the same species. Consequently, the priority name is Orobanche serbica, because it was the first published correctly according to ICN. Genetic studies indicated that Orobanche serbica is a relatively closely related to Orobanche santolinae Loscos \& J. Pardo and Orobanche loscosii L. Carlón, M. Laínz, G. Moreno Moral \& Ó. Sánchez Pedraja (Carlón et al., 2008) (Orobanche santolinae EU65516; Orobanche loscosii EU655617, sub Orobanche ritro; Orobanche serbica AY960723, La Grave,
France, sub O. ozanonis) which is in line with earlier assumptions of Beck (1890), but Orobanche serbica, due to the small size of the corolla lobes [(Carlón et al., 2002) sub Orobanche cf. artemisiae-campestris; (Carlón et al., 2005) sub Orobanche ozanonis; (Sánchez Pedraja et al. 2016)], is easily differentiated from Orobanche santolinae (Carlón et al., 2003; Sánchez Pedraja et al., 2016) and Orobanche loscosii [sub "O. major L. $\beta$ Ritro" (Carlón et al., 2003, 2011)].

\section{Examined specimens (new records)}

Italy: Parma Province: "Orobanche dell'artemisa campestre. Passo della Cisa-Terenzo (PR), 700 m, giu 2018” (photos! by Ezio Sacchi [sub O. artemisiae-campestris Gaudin] in Acta Plantarum Flora delle Regioni italiane.

\section{Phelipanche lavandulacea (Rchb.) Pomel} (Orobanchaceae)

Synonyms: Orobanche lavandulacea Rchb.

Contributors - Óscar Sánchez Pedraja, Renata Piwowarczyk, Gonzalo Moreno Moral

\section{Distribution and habitat}

Phelipanche lavandulacea is a species described from Italy (Reichenbach, 1829). It is characterized by a Mediterranean distribution (Sánchez Pedraja et al., 2016). Phelipanche lavandulacea is relatively common in the European part of the Mediterranean region as well as in the northwest part of Africa. Its occurrence in northeast Africa is doubtful. Finally, it is rare in southwest Asia (Turkey, Palestine, Israel). Some records from Asian countries (e.g. Syria, Iran) have not been confirmed so far. We encountered three sheets with specimens representing P. lavandulacea in the herbaria LE and MW. The plant materials were collected in the Russian district of Sochi (Krasnodar Krai). Thus, the eastern boundary of the species extends to the northeastern coast of the Black Sea. It usually occurs in rocky places, sunny slopes, the edges of shrublands, ruderal habitats. The species is indicated as a new, native taxon to the Russian flora.

\section{Taxonomic notes}

This species is easily recognizable by its habit (plants usually tall, inflorescences are simple or branched, dense and many-flowered, rarely lax and few-flowered, flowers 15-23 mm with calyx-teeth equalling or slightly longer than calyx-tube, corolla deep-violet and anthers hairy) and the fact that it has only one confirmed host-plant, Bituminaria bituminosa (L.) C. H. Stirt. (= Psoralea bituminosa L.). Two subspecies, i.e. subsp. lavandulacea and subsp. trichocalyx (Webb) Carlón, G. Gómez, M. Laínz, Moreno Mor., Ó. Sánchez \& Schneew. (Carlón et al., 2008; Piwowarczyk, 2016), are distinguished within this taxon. The latter is considered to be endemic to the Canary Islands (Carlón et al., 2008). Reuter (1847) (sub Phelipaea lavandulacea) believed that Orobanche lavandulacea Rchb., Phelypaea trichocalyx Webb and Orobanche schultzii 
Mutel are conspecific species. Recently, the last species is considered as clearly separate (e.g. by its long calyx teeth). According to Schultz (1842-1855) Orobanche schultzii differs from Phelipanche lavandulacea in both morphology and its host. Another species, Phelipanche lavandulaceoides Carlón, G. Gómez, M. Laínz, Moreno Mor., Ó. Sánchez \& Schneew., is also parasitic on Bituminaria bituminosa and based on this common host could be confused with Phelipanche lavandulacea, but morphologically and genetically it is perfectly distinguishable. Besides, it is limited to the interior areas of the Iberian Peninsula (Carlón et al., 2008). This species has also been confused with other species of the same genus for its coloration or habit, e.g., Phelipanche rosmarina [(Welw. ex) Beck (1921)] Banfi, Galasso \& Soldano, Phelipanche cernua Pomel, Phelipanche schultzii (Mutel) Pomel, Phelipanche heldreichii (Reut.) Soják, Phelipanche libanotica (Schweinf. ex Boiss.) Soják (Phelipanche orientalis (Beck) Soják), but their hosts, morphology, genetics and range of distribution are different (Sánchez Pedraja et al., 2016).

Examined specimens (new records)

Russia: Caucasus, Black Sea coast, Krasnodar Krai, Sochi distr.: Chernomorskaya gub., Sochinskyi okruh, urochische Ashe, on the southwestern slope of the mountain with the sea exposure, stony soil mixed with clay, [as Orobanche dalmatica (G. Beck) Tzvel. by Tzvelev 1988], 10 June 1904, Afanasyeva (Afanas'eva) (LE); Ashe, [as Orobanche mutelii F. Schultz by A. Zernov 2004], 20 May ??, V. Miller (MW0717030); Chermomorskaya oblast', Tuapsinskyi okruh [Tuapse], Lazarevskoye village [Lazarevsky City District - district of the city of Sochi], oak forest near the willow, [as Orobanche coerulea Vill.], 24 June 1917, N.V. Pavlov (MW0717052).

\section{Rubus austroslovacus Trávn. (Rosaceae)}

Contributor - Gergely Király

Distribution and habitat

Rubus austroslovacus is a widespread central European bramble species that was reported from Austria, the Czech Republic, Hungary, Poland, Slovakia, Germany and France (Trávníček and Zázvorka, 2005 ; Kurtto et al., 2010). Rubus austroslovacus, as a thamnophilous species preferring semi-dry to mesic soils on limestone or base-rich eruptive bedrocks, usually occurs in mixed oak-hornbeam forests of submontane regions.

During the herbarium revisions in BP I found two specimens of Rubus austroslovacus in the material collected by Antal Margittai in the 1930s on the foothills of the Northeastern Carpathians in the surroundings of Mukacevo (at that time Czechoslovakia, today Transcarpathian region of Ukraine). These records extend the known range by about $75 \mathrm{~km}$ eastwards.

Taxonomic notes

Rubus austroslovacus belongs to the taxonomically complicated species-rich triploid group of Rubus ser.
Discolores (P.J.Müll.) Focke (Krahulcová et al., 2013). It is characterized by narrowly to broadly elliptical leaflets with parallel margins of the first-year stem, broadly cylindrical to pyramidal inflorescence with long erectopatent branches, white (rarely slightly pinkish) flowers, and densely hairy ovaries - for more details concerning identification and comparison with similar species see Trávniček and Zázvorka (2005).

\section{Examined specimens (new records)}

Ukraine: Transcarpathia (Zakarpattia Oblast): in fruticosis ad Seredně, Ung, c. $150 \mathrm{~m}$ [in coppices near Seredně, Ung County], 17 July 1935, A. Margittai (BP85227) (as R. vestii Focke); in monte Nagyhegy ad Ardó, Bereg [=Mt. Nagyhegy near Ardó (today part of Beregovo), Bereg County], 25 July 1935, A. Margittai (BP85179) (as R. vestii Focke).

\section{Rubus crispomarginatus Holub (Rosaceae)}

Contributor - Gergely Király

Distribution and habitat

Rubus crispomarginatus was described as a regional species from the Czech Republic and Slovakia (Holub, 1991). Later it was also recorded in southern Poland (Zieliński, 2004) and in northeastern Hungary, whereas its presence in Austria is uncertain (Kurtto et al., 2010). The species occurs in sunny fringes of oak-hornbeam or beech forests mainly on base-rich, shallow soils. One herbarium sheet with Rubus crispomarginatus (identified earlier erroneously as Rubus vestii Focke [= Rubus constrictus Lefèvre \& P.J.Müll.]) was recognized during recent herbarium revisions in $\mathrm{BP}$, in the material collected by Antal Margittai in 1935 in the Northeastern Carpathians north of Uzhorod (at that time Czechoslovakia, today Transcarpathian region of Ukraine). This is one of the easternmost localities of the species, and is apparently connected with the adjacent populations in eastern Slovakia and southeastern Poland (Zieliński, 2004; Kurtto et al., 2010).

\section{Taxonomic notes}

Rubus crispomarginatus is a representative of the taxonomically complicated triploid group of Rubus ser. Discolores (P.J.Müll.) Focke (Krahulcová et al., 2013), however, contrary to the other species, it can be easily distinguished by the strongly furrowed stem and the deeply serrated and conspicuously crispate leaves of the primocane (Holub, 1991; Trávníček and Zázvorka, 2005).

\section{Examined specimen (new record)}

Ukraine: Transcarpathia (Zakarpattia Oblast): in silvis ad N. Berezna, Ung, c. 150 m [in forests near NagyBerezna (today Velikij Bereznij), Ung County], 18 June 1935, A. Margittai (BP85435) (as R. vestii Focke).

\section{Rubus phoenicolasius Maxim. (Rosaceae)}

Contributors - Gergely Király, Pavol Eliaš jun

Distribution and habitat 
Rubusphoenicolasius, native to the Far East, was brought to European and North American gardens between 1870 and 1890 (Weber, 1995). It is naturalized and widespread in central Europe and the British Isles (Kurtto et al., 2010). The species has not been mentioned by Kurtto et al. (2010) from Slovakia, however, there is a note in Medvecká et al. (2012) that it was found as a casual alien in this country in 1948. Nevertheless, after long search for the latter record, we could not find any supporting herbarium material or exact source of the publication.

During the revision of bramble collections in Slovak herbaria, a specimen of $R$. phoenicolasius collected in 1979 in Bratislava, most probably originated from a subspontaneous stand, was found in SLO and it represents the only known voucher for this species in Slovakia.

\section{Taxonomic notes}

Rubus phoenicolasius is a diploid member of Rubus subgen. Ideobatus (Focke) Focke (Weber, 1995; Kurtto et al., 2010). This subgenus is represented in the European flora only by Rubus idaeus L. Distinctive morphological characters of $R$. phoenicolasius: leaves 3-5-foliolate, densely tomentose beneath; stem, rachis and pedicels pubescent with reddish bristles, stalked glands and prickles; inflorescences few-flowered, petals red, significantly longer than sepals; drupelets orange or red (Lingdi and Boufford, 2003).

\section{Examined specimen (new record)}

Slovakia: Bratislava, Devínska Kobyla, za blatom, cesta Hrdinov SNP, 16 Aug 1979, M. Mičieta (SLO).

\section{Taraxacum acervatulum Rail., section Taraxacum}

Contributors - Jolanta Marciniuk, Paweł Marciniuk, Mateusz Wolanin

\section{Distribution and habitat}

Taraxacum acervatulum is a broad-range species occurring in western Europe (Spain, France, Germany), central Europe (the Czech Republic, Slovakia, Poland) and in Finland (Kirschner and Štěpánek, 2007). According to our study, T. acervatulum should be considered a new native species to Ukraine (Figure 7). Recently, several hundred individuals have been found in Lviv. The species occurs in meadows and on grassy anthropogenic habitats.

Taxonomic notes

Taraxacum acervatulum sect. Taraxacum belongs to the Taraxacum retroflexum $\mathrm{H}$. Lindb. group, which includes plants with outer bracts usually recurved, broad, brightly coloured, with clear and narrow margin; leaves with more or less red petioles and wide, often divided, terminal lobes. Main diagnostic features of Taraxacum acervatulum are: petioles red and narrowly winged; leaves lobed, side lobes recurved, deltoid, often with large teeth on the upper and lower edges; terminal lobes greater than the side lobes, often divided with a distinct tip; outer bracts recurved, with clearly distinct margin, 3-4.5 mm wide; capitulum with a diameter of ca. $55 \mathrm{~mm}$, convex; stigmas discolored; pollen present.

Examined specimens (new records)

Ukraine: Lviv, High Castle, urban lawn 49'50'44”N / 2402'06”'E, 9 May 2017, J. \& P. Marciniuk (WSRP); Lviv, Lychakiv Cemetery, lawns at cemetery avenues 49 $49^{\prime} 56^{\prime \prime} \mathrm{N}$ / 2403'11"E, 8 May 2017, J. \& P. Marciniuk (WSRP).

Taraxacum aequilobum Dahlst., section Taraxacum (Asteraceae)

Contributors - Jolanta Marciniuk, Paweł Marciniuk, Mateusz Wolanin

\section{Distribution and habitat}

Taraxacum aequilobum has a broad range comprising the western, central, eastern and northern Europe. Up to now the species has been recorded from Spain, Belgium, the Netherlands, Germany, Switzerland, the Czech Republic, Slovakia, Poland, Denmark, Norway, Sweden, Finland, Estonia, Latvia, Lithuania, the European part of Russia and Belarus; in the British Isles it is probably an alien species (Kirschner and Štěpánek, 2007). A new population of $T$. aequilobum (about 100 individuals) was found along the roadside in Fraga (western Ukraine). The species grows there in meadows and in grassy anthropogenic habitats. Taraxacum aequilobum is a new native species to Ukraine.

Taxonomic notes

Taraxacum aequilobum sect. Taraxacum in terms of morphology belongs to the Taraxacum retroflexum group. The group includes plants with leaves with numerous uniform usually entire lobes pairs and winged petioles; the outer bracts are quite large and irregularly arranged. Main diagnostic features of this taxon are: red clearly winged petioles; leaves with numerous symmetrical and usually identical pairs of lobes; side lobes recurved, deltoid, medium acute with falcate upper edge; terminal lobe similar to side lobes blunt to acute sometimes with distinct tip; outer bracts irregularly recurved and strongly twisted 4-9.9 $\mathrm{mm}$ wide, 15-17 mm long, without a margin; capitulum with a diameter of ca. $50 \mathrm{~mm}$, convex; stigmas discolored; pollen present (Figure 7).

Examined specimens (new record)

Ukraine: Fraga, $49^{\circ} 28^{\prime} 04^{\prime \prime} \mathrm{N} / 24^{\circ} 26^{\prime} 48^{\prime \prime} \mathrm{E}$, roadside (on limestone soil), 12 May 2017, K. Oklejewicz, M. Wolanin (KRA).

Taraxacum amplum Markl., section Taraxacum (Asteraceae)

Contributors - Jolanta Marciniuk, Paweł Marciniuk, Mateusz Wolanin

Distribution and habitat

Taraxacum amplum is a species widespread in central, northern and eastern Europe. As a native species has been noted in Denmark, the Netherlands, Germany, the Czech Republic, Slovakia, Poland, Ukraine, Latvia, Estonia, Finland, Norway, Sweden and the northern part 
of European Russia. It is probably alien to the flora of the British Isles (Kirschner and Štěpánek, 2007). A few localities of $T$. amplum were encountered during field studies conducted in the western part of the Ukraine in 2017. The populations of the species were quite large, each consisted of several hundred individuals. The species was noted in meadows and on grassy anthropogenic habitats. We consider Taraxacum amplum as a new, native species to the flora of Ukraine.

\section{Taxonomic notes}

Taraxacum amplum sect. Taraxacum belongs to the Taraxacum copidophyllum Dahlst. group. The group includes species morphologically similar to taxa from Taraxacum sect. Palustria having leaves with few, usually undivided, side lobes and large terminal lobes; the outer bracts ovate or broadly lanceolate, erect or horizontally arranged with distinct margins. Main diagnostic features of Taraxacum amplum include: light green leaves; petioles unwinged, red, side lobes not very numerous, recurved deltoid, usually with entire edges; terminal lobes large, sagittate; outer bracts broadly lanceolate $4-4.9 \mathrm{~mm}$ wide and $14-15 \mathrm{~mm}$ long, horizontally or slightly recurved, clearly bordered; capitulum $50 \mathrm{~mm}$ in diameter, usually strongly convex; stigmas discolored; pollen present (Figure 7).

Examined specimens (new records)

Ukraine: Lviv, city park, lawn 49 $50^{\prime} 13^{\prime \prime} \mathrm{N} / 24^{\circ} 01^{\prime} 28^{\prime \prime} \mathrm{E}$, 8 May 2017, J. \& P. Marciniuk (WSRP); Lviv, Lychakiv Cemetery, lawns at cemetery avenues $49^{\circ} 49^{\prime} 56^{\prime \prime} \mathrm{N}$ / 2403'11"E, 8 May 2017, J. \& P. Marciniuk (WSRP); Lelechovka, Yavorivskiy National Park, meadow 49 57’01"N / 2441'25”E, 11 May 2017, J. \& P. Marciniuk (WSRP); Fraga, roadside (on limestone soil), 49 $28^{\prime} 04^{\prime \prime} \mathrm{N}$

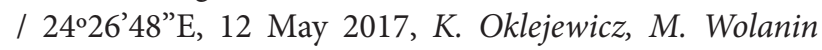
(KRA).

\section{Taraxacum ancistrolobum Dahlst., section Taraxacum (Asteraceae)}

Contributors - Jolanta Marciniuk, Paweł Marciniuk, Mateusz Wolanin

\section{Distribution and habitat}

Taraxacum ancistrolobum is known from central, northern and western Europe. It was recorded from France, British Isles, Switzerland, Belgium, the Netherlands, Denmark, Germany, the Czech Republic, Poland, Slovakia, Sweden, Norway, Finland and northwestern Russia (Kirschner and Štěpánek, 2007). It occurs in meadows and on grassy anthropogenic habitats. A new locality of the species was found during field studies in the western Ukraine in 2017. The population of T. ancistrolobum occurred on a marshy meadow and comprises about 200 individuals. We consider the species as a new, native species to the flora of Ukraine.

\section{Taxonomic notes}

Taraxacum ancistrolobum sect. Taraxacum belongs to the Taraxacum lucidum Dahlst. group. The group comprises taxa with stout, often crispate leaves, usually with a large terminal lobe, side lobes blunt to obtuse; the outer bracts are ovate or ovate-lanceolate, usually clearly bordered. Its main diagnostic features include: late flowering, stout, dark green leaves, sometimes with tarry spots in interlobes, lateral lobes undivided, broad, blunt, with usually entire, convex upper edge and concave lower edge; terminal lobe is not larger than the side lobes, blunt, broadly triangular, petioles broadly winged, green sometimes slightly pink on the inside; outer bracts ovate-lanceolate $4.0-4.9 \mathrm{~mm}$ wide and $12-13 \mathrm{~mm}$ long, horizontally arranged, usually narrowly bordered; capitulum convex with a diameter of ca. $50 \mathrm{~mm}$; stigmas discoloured; pollen present (Figure 7).

Examined specimens (new record)

Ukraine: Hodortivts (Hodorkowce), 49 $35^{\prime} 00.1^{\prime \prime} \mathrm{N} /$ $24^{\circ} 16^{\prime} 46.0^{\prime \prime}$, marshy meadow, 12 May 2017, K. Oklejewicz, M. Wolanin (KRA).

Taraxacum bellicum Sonck, section Erythrosperma (Asteraceae)

Synonyms: Taraxacum prunicolor M. Schmid, Vašut \& Oosterveld

Contributors - Jolanta Marciniuk, Paweł Marciniuk, Mateusz Wolanin

\section{Distribution and habitat}

Taraxacum bellicum has been previously reported from: Austria, Switzerland, the Czech Republic, Slovakia, Poland, Germany, and Finland (Kirschner and Štěpánek, 2007; Marciniuk et al., 2009). We found one population (consisting of several dozen individuals) growing along a sandy forest road in the Yavorivskiy National Park, western Ukraine. Taraxacum bellicum is a new, native species to the flora of Ukraine.

\section{Taxonomic notes}

Taraxacum bellicum sect. Erythrosperma (Figure 6) is very similar to Taraxacum scanicum Dahlst. The two species differ in arrangement and coloration of the outer bracts. Main diagnostic features of Taraxacum bellicum are: leaves strongly cut, medium-green, glabrous; lateral lobes in 3-5 pairs, straight or slightly recurved, sharpended, their upper edges entire or slightly denticulate; terminal lobe of outer leaves triangular, while of inner leaves usually slightly elongated, lingulate with more dense small lobes below; petiole unwinged, pale purple to pale brown-purple; scapes usually green, covered with araneous hairs only below capitulum; outer bracts lanceolate, regularly recurved $1.0-3.0 \mathrm{~mm}$ wide, $6.5-9.0$ $\mathrm{mm}$ long, usually red-violet, indistinctly bordered, more or less distinctly corniculate; capitulum slightly convex, 20-30 $\mathrm{mm}$ in diameter, flowers dark yellow, stigmata discoloured, pollen present; achenes greyish purple- 

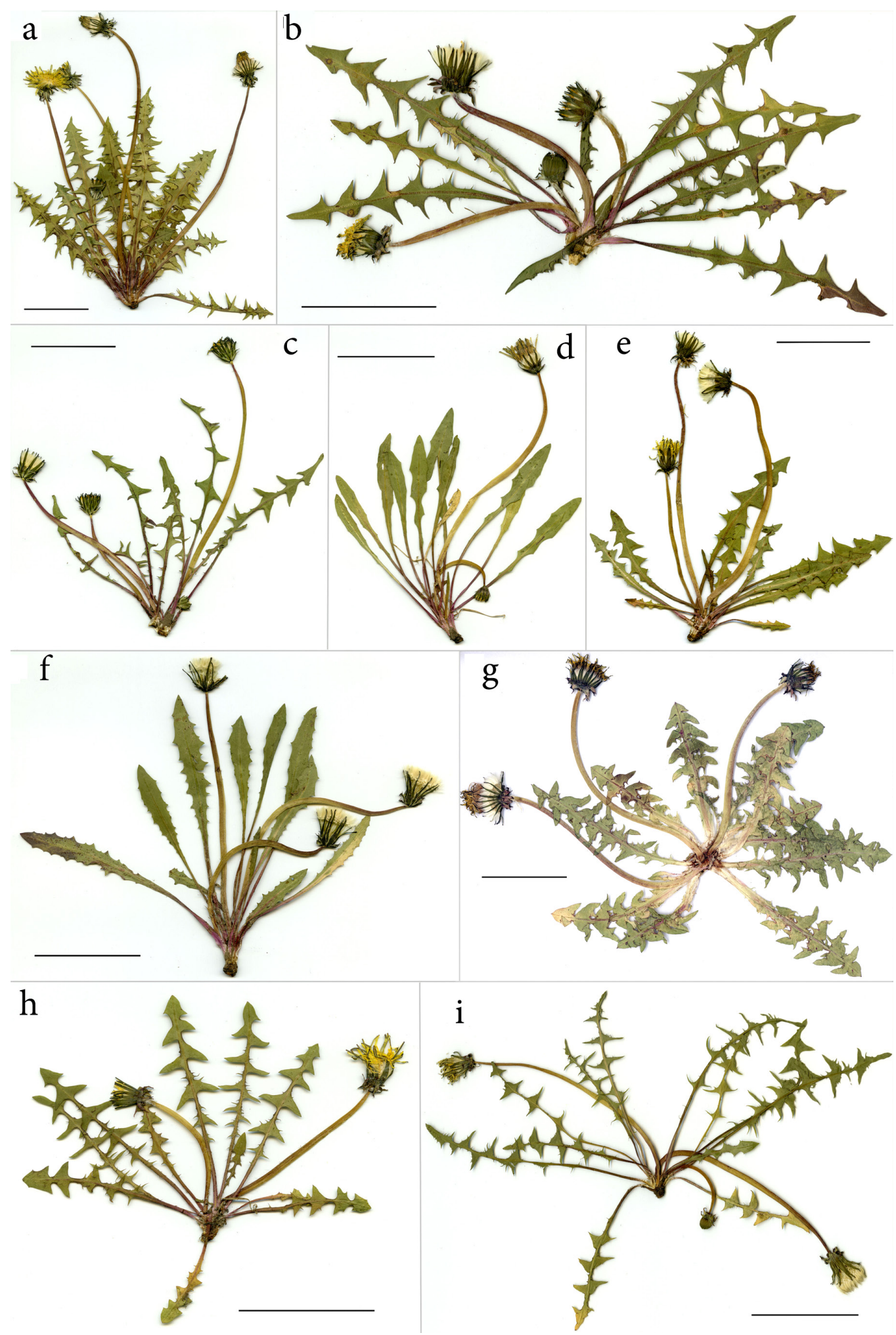

Figure 6. Taraxacum collarispinulosum Uhlemann from Lviv (a), Taraxacum dentatum Kirschner \& Štěpánek from Lozina/Dabrovnitsa (b), Taraxacum portentosum Kirschner \& Štěpánek from Novosilky (c), Taraxacum paucilobum Hudziok from Lelechovka (d), Taraxacum gelertii Raunk. from Lelechovka (e), Taraxacum telmatophilum Kirschner \& Štěpánek from Novosilky (f), Taraxacum undulatum H. Lindb. (Lindb. et Markl.) from Lozina/Dabrovnitsa (g), Taraxacum bellicum Sonck from Lelechovka (h), Taraxacum plumbeum Dahlst. from Stradcz (i) in Ukraine, phot. M. Wolanin, J. Marciniuk \& P. Marciniuk. 


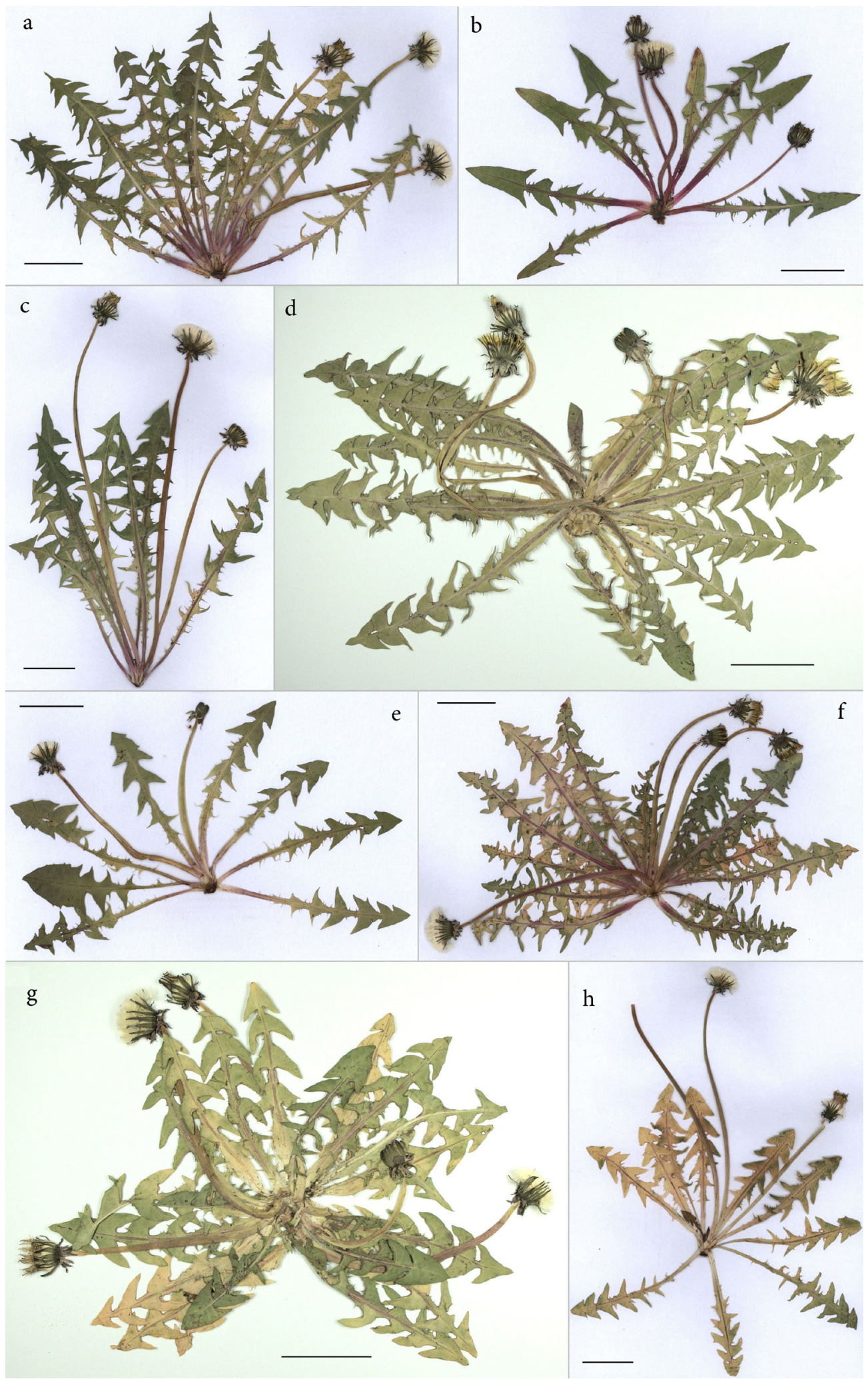

Figure 7. Taraxacum acervatulum Rail. from Lviv (a), Taraxacum copidophyllum Dahlst. from Lozina/Dabrovnitsa (b), Taraxacum amplum Markl. from Lviv (c), Taraxacum aequilobum Dahlst. from Fraga (d), Taraxacum subhuelphersianum M.P.Chr. from Lviv (e), Taraxacum sinuatum Dahlst. from Lozina/Dabrovnitsa (f), Taraxacum ancistrolobum Dahlst. from Hodortivts (g), Taraxacum undulatiforme Dahlst. from Wola (h) in Ukraine, phot. M. Wolanin, J. Marciniuk \& P. Marciniuk. 
brown, brown after drying, rarely spinulose on the top, 3.2-3.6 mm long, cone narrow $0.9-1.1 \mathrm{~mm}$ long, rostrum 6-7 mm long, pappus ca. $6 \mathrm{~mm}$ long, white.

Examined specimens (new record)

Ukraine: Lelechovka, Yavorivskiy National Park, roadside in the forest, $49^{\circ} 56^{\prime} 45^{\prime \prime} \mathrm{N} / 2^{\circ} 41^{\prime} 21^{\prime \prime} \mathrm{E}, 11$ May 2017, M. Wolanin (KRA).

Taraxacum collarispinulosum Uhlemann, section Borea (Asteraceae)

Contributors - Jolanta Marciniuk, Paweł Marciniuk, Mateusz Wolanin

\section{Distribution and habitat}

Distribution of Taraxacum collarispinulosum is very poorly recognized. It has been previously reported only from central and eastern Germany (Uhlemann, 2004; Kirschner and Štěpánek, 2007). We found quite a large population (consisting of about 250 individuals) of this species on lawns in the southern periphery of the city of Lviv. We consider the species as new native species to the flora of Ukraine.

Taxonomic notes

Uhlemann (Uhlemann, 2004) assigned Taraxacum collarispinulosum to Taraxacum section and to Taraxacum melanostigma H.Lindb. group. This group is 'transitional' between the Borea and Taraxacum sections. The features such as: relatively small capitulae, narrow outer bracts and the lack of pollen indicate close relationship of Taraxacum collarispinulosum with the Borea section. As Kirschner, Štěpánek, and Greuter (Kirschner and Štěpánek, 2007) assigned Taraxacum melanostigma to the Borea section based on the same characters, we incline to the view that Taraxacum collarispinulosum should also be included in the Borea section. Main diagnostic features of Taraxacum collarispinulosum (Figure 6) are: green to grey-green leaves, usually smooth or poorly hairy lateral lobes in (5-)6-7 pairs, deltoid, patent or slightly recurved, acute, while upper edge usually with parallel cut or large tooth, more rarely with a row of small teeth; terminal lobe usually small, often ligulate-elongated; interlobes acute, often tar-coloured; petiole narrowly winged, pale violet, midrib green or brown-flushed; scape below the capitulum covered densely with araneous hairs; involucre blackish; outer bracts grey-green without white edge, regularly recurved, narrowly lanceolate, $1.5-2.5 \mathrm{~mm}$ wide, $14-17$ $\mathrm{mm}$ long; capitulum, $35-40 \mathrm{~mm}$ in diameter, stomata dark, blackish, pollen absent or residual; achenes dark straw-coloured, 3.3-3.8 mm long (without cone), collarshaped spinulose on the top; cone cylindrical, smooth, ca. $0.5 \mathrm{~mm}$ long; rostrum ca. $10 \mathrm{~mm}$ long; pappus white ca. 6 mm long.

Examined specimens (new record)

Ukraine: Lviv, Czerniowiecka street, 49050'13"N / 2400'00"E lawn, 9 May 2017, M. Wolanin (KRA).

\section{Taraxacum copidophyllum Dahlst., section Taraxacum (Asteraceae) \\ Contributors - Jolanta Marciniuk, Paweł Marciniuk, Mateusz Wolanin \\ Distribution and habitat}

Species known from the: Belgium, Netherlands, Denmark, Germany, Poland, the Czech Republic, Slovakia, Norway, Sweden, Finland, northwestern part of Russia and mountain areas of Greece (Kirschner and Štěpánek, 2007). We found two localities of this species during field studies in the western Ukraine. The species grew in wet meadows and pastures. Its populations consisted of about 500 individuals in total. To our knowledge Taraxacum copidophyllum is a new native species to Ukraine.

\section{Taxonomic notes}

Taraxacum copidophyllum sect. Taraxacum belongs to the T. copidophyllum group. Main diagnostic features of this taxon (Figure 7) are: leaves dark-green with few (2-3) recurved, undivided side lobes and large hastate terminal lobes; petioles lucidly purple usually unwinged; outer bracts erect, ovate above $5 \mathrm{~mm}$ wide and $10-11 \mathrm{~mm}$ long, dark colored with a strongly contrasting white edge; capitulum with a diameter of ca. $40 \mathrm{~mm}$, convex; stigmas discolored; pollen present.

\section{Examined specimens (new records)}

Ukraine: Between Lozina and Dabrovnitsa,

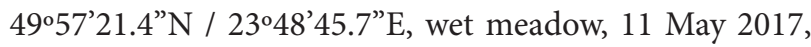
J. \& P. Marciniuk (WSRP); Hodortivts (Hodorkowce), $49^{\circ} 35^{\prime} 00.1^{\prime} \mathrm{N} / 24^{\circ} 16^{\prime} 46.0^{\prime \prime} \mathrm{E}$, wet pasture, 12 May 2017, K. Oklejewicz, M. Wolanin (KRA).

Taraxacum corynodes G.E.Haglund, section Taraxacum (Asteraceae)

Contributors - Jolanta Marciniuk, Paweł Marciniuk, Mateusz Wolanin

\section{Distribution and habitat}

Species known from central and northern Europe: Denmark, Sweden, Finland, Germany, Poland, the Czech Republic, Slovakia and Ukraine. It is considered to be alien to the British Isles (Kirschner and Štěpánek, 2007). It occurs in meadows and on grassy anthropogenic habitats. We found one location of this species in the Lviv region (western Ukraine). Dozens of individuals grew on an extensively used wet meadow. To our knowledge Taraxacum corynodes is a new, native species to Ukraine.

Taxonomic notes

Taraxacum corynodes sect. Taraxacum belongs to the Taraxacum lucidum group. Main diagnostic features of this taxon are: side lobes densely arranged, recurved deltoid or patent triangular, blunt with a pronounced tendency to divide, upper edges straight or irregular, often with large teeth, lower edges irregularly concave usually with conspicuous teeth, petioles green clearly winged; outer bracts $4-4.9 \mathrm{~mm}$ wide and $12-13 \mathrm{~mm}$ long, recurved, 
unbordered; capitulum convex ca. $50 \mathrm{~mm}$ in diameter, stigmas discolored, pollen present.

\section{Examined specimens (new record)}

Ukraine: Between Lozina and Dabrovnitsa, 49 $57^{\prime} 21.4^{\prime \prime} \mathrm{N} / 23^{\circ} 48^{\prime} 45.7^{\prime \prime} \mathrm{E}$, wet meadow, 11 May 2017, J. \& P. Marciniuk (WSRP).

Taraxacum dentatum Kirschner \& Štěpánek, section Palustria (Asteraceae)

Contributors - Jolanta Marciniuk, Paweł Marciniuk, Mateusz Wolanin

\section{Distribution and habitat}

Taraxacum dentatum is a central European species, occurring from eastern Germany, through Poland, the Czech Republic, Slovakia, up to the area of Hungary (Kirschner and Štěpánek, 1998). We found three locations of Taraxacum dentatum in the Lviv District. The species occurred on extensively used wet meadows, preferring places with low vegetation. In total, the population consisted of several hundred individuals. In Ukraine (similarly as in other countries), it is probably a rare species. According to our study, $T$. dentatum should be now regarded as a new native species to Ukraine.

\section{Taxonomic notes}

Taraxacum dentatum sect. Palustria (Figure 6) is included by Kirschner and Štěpánek (1998) to the group of Taraxacum turfosum (Sch.Bip.) Soest and Taraxacum dentatum. The two species differ in achenes length (ca. $3.5 \mathrm{~mm}$ vs. ca. $4 \mathrm{~mm}$, respectively) and shape of the distal margins of lateral lobes (Taraxacum dentatum has dentate Taraxacum turfosum has entire margins). Main diagnostic features of Taraxacum dentatum are: leaves erect and straight, narrow, up to $1.5 \mathrm{~cm}$ wide, medium-green, sinuate-dentate or deeply lobed, more rarely only toothed; lateral lobes 2 or 3, (rarely more), slightly recurved, widetriangular, upper edge straight, usually toothed; terminal lobe narrow-triangular, fairly sharp-ended, interlobes short or medium-sized, entire; petiole narrow, purple; scape pale brownish-greenish, sparsely covered with araneous hairs capitulum, $2-3 \mathrm{~cm}$ in diameter, stigmata greenishgreyish, pollen present; outer bracts (11-)12-14(-18), loosely adpressed or sometimes recurved at the base, not imbricate, smooth, non-ciliate, narrowly lanceolate, 6.5-8.5 $\mathrm{mm}$ long, $1.5-2.8 \mathrm{~mm}$ wide, their edge sometimes clearly narrower than the rest part of the bract; borders of bracts indistinct, greenish to whitish-greenish, 0.4-0.9 mm wide (together with membranous $0.1-0.2 \mathrm{~mm}$ wide edge), gradually turning into the middle part; achenes (2.9-)3.3$3.8 \mathrm{~mm}$ long, spinulose on the top, fairly rapidly narrowing into more or less cylindrical $0.5-0.7(-0.8) \mathrm{mm}$ long cone; rostrum 6.5-7.0(-8.0) $\mathrm{mm}$ long; pappus 5.5-6.0 $\mathrm{mm}$ long.

Examined specimens (new records)

Ukraine: Between Lozina and Dabrovnitsa, 4957'21'N / 23⒋ 45"E, wet meadow, 11 May 2017, J. \& P. Marciniuk
(KRA); Iwano-Franko, 495' $36^{\prime \prime} \mathrm{N} / 23^{\circ} 44^{\prime} 33^{\prime \prime} \mathrm{E}$, meadow in the Wereszczyca river valley, 11 May 2017, J. \& P. Marciniuk

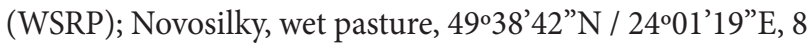
May 2017, K. Oklejewicz (KRA).

Taraxacum gelertii Raunk., section Naevosa (Asteraceae)

Contributors - Jolanta Marciniuk, Paweł Marciniuk, Mateusz Wolanin

\section{Distribution and habitat}

Taraxacum gelertii is the most widespread species from the subatlantic section Naevosa. It has been reported from Portugal, Belgium, the British Isles, Denmark, Germany, the Czech Republic, Poland, Sweden, Finland, Latvia and Estonia (Kirschner and Štěpánek, 2007). For the first time the species was found in Ukraine in three localities (several hundred individuals) where it grew mainly on wet meadows, rarely in anthropogenic habitats: parks, urban lawns, cemeteries. To our study, T. gelertii should be regarded as a new native species (and the section Naevosa as a new section) to the flora of Ukraine.

\section{Taxonomic notes}

Taraxacum gelertii (together with Taraxacum praestans H.Lindb. and Taraxacum adamii C.Claire) occupies a marginal position within the section Naevosa. This is due to the lack of scattered spots on the leaf, which are characteristic for this section. Taraxacum gelertii (Figure 6) clearly differs from Taraxacum adamii and Taraxacum praestans by having green, not purple, leaf midrib. Main diagnostic features of Taraxacum galertii are: leaves usually nearly erect, greyishgreen, usually shallowly lobed, more rarely only denticulate; lateral lobes (small lobes, teeth) usually $3-4(-5)$, protruded at the right angle, narrowly triangular or nearly linear (in young plants developing under extreme conditions), irregularly denticulate or small-lobed, upper edge usually concave; interlobes denticulate and small-lobed, terminal lobe small, triangular; petiole narrow, pale purple; scape suffused with brownish-purple, araneous hairy; capitulum $2.5-3.0 \mathrm{~cm}$ in diameter, flowers yellow; stomata green; pollen present; the outer bracts (10-)13-15, adpressed to loosely adpressed, not imbricate, ciliated, blackish, narrowly lanceolate or lanceolate (6.5-)7.0-8.0(-9.5) $\mathrm{mm}$ long, (2.7-)2.9-3.3 mm wide; border of bracts distinctly limited to whitish and narrow $0.2-0.3 \mathrm{~mm}$ wide edge; achenes $4.2-$ $4.5 \mathrm{~mm}$ long, evidently spinulose on the top, fairly rapidly narrowing into +/- cylindrical cone $0.9-1.0 \mathrm{~mm}$ long; rostrum 7.0-8.0 $\mathrm{mm}$ long; pappus 5.5-6.0 $\mathrm{mm}$ long.

Examined specimens (new records)

Ukraine: Lelechovka, 4956'45”N / 2341'21'E, marshy meadow, 11 May 2017 J. \& P. Marciniuk, M. Wolanin (WSRP); Stradcz, 49054'02"N / 2345'34"E, meadow, 11 May 2017 J. \& P. Marciniuk, K. Oklejewicz (WSRP); Lviv,

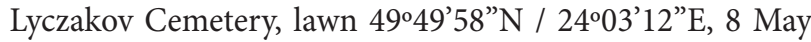
2017, J. \& P. Marciniuk (WSRP). 
Taraxacum infuscatum H. Øllg., section Taraxacum (Asteraceae)

Contributors - Jolanta Marciniuk, Paweł Marciniuk, Mateusz Wolanin

\section{Distribution and habitat}

Taraxacum infuscatum is a species with poorly known distribution. It was previously reported from France, the Netherlands, Denmark, Sweden, Finland, Germany, the Czech Republic and Poland (Kirschner and Štěpánek, 2007). It occurs in meadows and on grassy anthropogenic habitats. We found the species in the anthropogenic habitats in Lviv and along the forest road in the Yavorivskiy National Park, Ukraine. During our field study in the western Ukraine a total of several hundred individuals were noted. Taraxacum infuscatum should be regarded as a new, native species to the flora of Ukraine

\section{Taxonomic notes}

Taraxacum infuscatum belongs to the Taraxacum retroflexum group. Main diagnostic features of this taxon are: petioles green, inside sometimes pink, winged; leaves with pronounced tar spots in interlobes and numerous curved deltoid side lobes, usually with a strongly serrated upper edge; terminal lobe small, triangular, often elongated; outer bracts vertical hanging, twisted and very long, 3-3.9 mm wide, 18-20 $\mathrm{mm}$ long, unbordered; capitulum with a diameter of ca. $50 \mathrm{~mm}$, convex; stigmas discolored; pollen present.

Examined specimens (new records)

Ukraine: Lviv, Lychakiv Cemetery, lawn 4949'56”N / 2403'11"E, 8 May 2017, J. \& P. Marciniuk (WSRP); Lviv, High Castle, lawn 4950'44”N / 2402'06”E, 9 May 2017, J. \& P. Marciniuk (WSRP); Lelechovka, Yavorivskiy National Park, forest road 4957’01"N / 2441'25”E, 11 May 2017, J. \& P. Marciniuk (WSRP).

Taraxacum ingens Palmgr., section Taraxacum (Asteraceae)

Contributors - Jolanta Marciniuk, Paweł Marciniuk, Mateusz Wolanin

\section{Distribution and habitat}

Taraxacum ingens is a species with a somewhat disjunctive range that is currently insufficiently recognized. It has been so far noted in Denmark, Germany, the Czech Republic, Slovakia, Poland, as well as in Latvia, Estonia and Finland (Kirschner and Štěpánek, 2007). Taraxacum ingens occurs in meadows and on grassy anthropogenic habitats. We found about 50 individuals of the species on a wet meadow in Stradcz (western Ukraine). The species should be now considered a new native species to Ukraine.

Taxonomic notes

Taraxacum infuscatum sect. Taraxacum belongs to the Taraxacum retroflexum group. Main diagnostic features of this taxon are: petioles winged, green without traces of red; leaves usually with numerous curved, deltoid side lobes with strongly serrated upper edges; terminal lobe obtuse to acute often with symmetrically placed large teeth; outer bracts large 4-4.9 and more mm wide and 15-17 $\mathrm{mm}$ long, often violet colored; capitulum over $60 \mathrm{~mm}$, convex; stigmas discolored; pollen present.

\section{Examined specimens (new record)}

Ukraine: Stradcz, 4950'44”N / 2402’06”E, meadow, 11 May 2017, J. \& P. Marciniuk (WSRP).

Taraxacum lucidum Dahlst., section Taraxacum (Asteraceae)

Contributors - Jolanta Marciniuk, Paweł Marciniuk, Mateusz Wolanin

\section{Distribution and habitat}

Taraxacum lucidum is a species with a fairly wide range, known from Spain, the British Isles, Belgium, the Netherlands, Denmark, Sweden, Norway, Finland, Estonia, Latvia, Germany, the Czech Republic, Slovakia and Poland (Kirschner and Štěpánek, 2007). A new locality of Taraxacum lucidum was found during fieldstudy in the western Ukraine. The population of the species included about 80 individuals. The species grows together with Taraxacum corynodes on a wet meadow. To our knowledge Taraxacum lucidum is a new native species to Ukraine. It occurs in wet meadows.

\section{Taxonomic notes}

Taraxacum lucidum sect. Taraxacum belongs to the T. lucidum group. Main diagnostic features of this taxon are: leaves stout, medium green with few recurved, mediumacute side lobes, their upper edges are strongly dentate, lower edges usually entire, terminal lobes large, blunt, more or less hastate, petioles of outer leaf usually pale outside and lucidly purple inside, inner leaves on both sides purple, uwinged; outer bracts large ovate over $5 \mathrm{~mm}$ wide and 12-13 mm long, erect or arranged horizontally, with clear margin; capitulum convex with a diameter of ca. $55 \mathrm{~mm}$; stigmas discolored; pollen present.

Examined specimens (new record)

Ukraine: Between Lozina and Dabrovnitsa, 4957'21.4”N / 2348'45.7”E, wet meadow, 11 May 2017, J. \& P. Marciniuk (WSRP).

Taraxacum paucilobum Hudziok, section Palustria (Asteraceae)

Contributors - Jolanta Marciniuk, Paweł Marciniuk, Mateusz Wolanin

Distribution and habitat

Taraxacum paucilobum is a central European species occurring in Poland, Slovakia, the Czech Republic, northern Austria, eastern and central Germany, and very rarely in Hungary, Romania, Bosnia and Herzegovina (Kirschner and Štěpánek, 1998). We found five populations of T. paucilobum (a total of 1000 individuals). The species occurred on extensively used wet meadows and wet pastures. To our knowledge, T. paucilobum is a new, native 
species to Ukraine. It is probably the most common species from the section Palustria in western Ukraine.

\section{Taxonomic notes}

Taraxacum paucilobum sect. Palustria (Figure 6) is included in the group of Taraxacum paucilobum and Taraxacum vindobonense Soest by Kirschner and Štěpánek (Kirschner and Štěpánek, 1998). It differs from the other species of the group (especially from the most similar Taraxacum polonicum Małecka \& Soest and Taraxacum vindobonense), by having slender achenes with a short rostrum, typically shallowly lobed leaves and tightly adpressed outer bracts. Taraxacum polonicum and Taraxacum vindobonense have thicker achenes, different leaf shape and loosely adpressed outer bracts. Main diagnostic features of Taraxacum paucilobum are: leaves prostrate to horizontally erected, longitudinally reversely lanceolate, medium-green, sinuate-serrated, sinuate-small lobate or lobate, more rarely almost entire; lateral lobes 2-3, more or less triangular; terminal lobe often elongated; petiole narrow, often long, purple; scape usually almost bare (below the capitulum very sparsely covered with araneous hairs), purplish from the top; capitulum small, $2.0-2.5 \mathrm{~cm}$ in diameter, flowers yellow; outer bracts 10-12, closely adpressed, not imbricate, sparsely ciliated, dark green and usually redish on the top, lanceolate or widely lanceolate, 4.0-6.0 mm long, 2.5-3.0 $\mathrm{mm}$ wide; borders of bracts $+/$ - visible, pale greenish and suffused with pink, $0.5-1.0 \mathrm{~mm}$ wide membranous edge +/- nonvisible, gradually transformed into the middle part; achenes $4.0-4.5 \mathrm{~mm}$ long, thin $(0.8-0.9 \mathrm{~mm}$ thick), sparsely spinulose on the top, fairly gradually narrowing into nearly cylindrical small cone, (0.7-)0.8-0.9 mm long; rostrum $6.0-7.0 \mathrm{~mm}$ long; pappus $5.0-6.0 \mathrm{~mm}$ long.

Examined specimens (new records)

Ukraine: Nowosilky, 49³8'42”N / 2401'19”E, wet pasture, 8 May 2017, M. Wolanin (KRA); Lelechovka, 49 56 $45^{\prime \prime}$ "N / 2341'1"E, wet meadow, 11 May 2017, M.

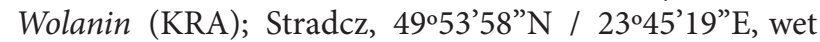
meadow, 11 May 2017, J. \& P. Marciniuk (WSRP); between Lozina and Dabrovnitsa, 495'ㄹ' meadow, 11 May 2017, J. \& P. Marciniuk (WSRP); IwanoFranko, 49 $54^{\prime} 36^{\prime \prime} \mathrm{N} / 23^{\circ} 44^{\prime} 33^{\prime \prime} \mathrm{E}$, wet meadow in the valley of the Wereszczyca River, 11 May 2017, J. \& P. Marciniuk (WSRP).

\section{Taraxacum plumbeum Dahlst., section Erythrosperma (Asteraceae)}

Contributors - Jolanta Marciniuk, Paweł Marciniuk, Mateusz Wolanin

\section{Distribution and habitat}

In Europe, Taraxacum plumbeum is a rare species. It has been reported so far from Italy, Switzerland, Austria, Slovakia, the Czech Republic, Poland, Germany, and Sweden (Kirschner and Štěpánek, 2007). The species occurs in dry, extensively used grasslands, on sandy forest roads and dry lawns. We found three locations of this taxon in the Lviv region (a total of several hundred individuals). Taraxacum plumbeum should be considered a new native species to the flora of Ukraine.

\section{Taxonomic notes}

In terms of morphology Taraxacum plumbeum (Figure 6) is similar to Taraxacum brachyglossum (Dahlst.) Raunk. The two species differ in coloration of the outer leaves (green vs. violet, respectively). Main diagnostic features of Taraxacum plumbeum are: leaves dark green, usually deeply cut, young leaves pilose; lateral lobes in 5-6 pairs, patent, or (in outer leaves) falcate, their upper edge often convex, entire or regularly toothed, interlobes with thread-like teeth and folded edge; terminal lobe of outer leaves usually small, triangular, while of inner leaves often lingulate-elongated with denticulate edge; petioles unwinged, usually red; scapes covered with araneous hairs; capitula convex, ca. $3 \mathrm{~cm}$ in diameter, stigmata (olivegreen); pollen present; the outer bracts erect, $2.0-2.9 \mathrm{~mm}$ wide, $7.0-9.0 \mathrm{~mm}$ long, unbordered or very narrowly bordered, usually not corniculate; achenes yellowish light redbrown, 3.9-4.1 $\mathrm{mm}$ long, densely spinulose on top; spinules fairly long and sturdy; cone cylindrical, $0.7-0.8$ $\mathrm{mm}$ long; rostrum 8.0-9.0 $\mathrm{mm}$ long, pappus ca. $6 \mathrm{~mm}$ long, white.

\section{Examined specimens (new records)}

Ukraine: Wola, 49³2'13"N / 240.1'14"E, dry grassland with Orchis morio, 10 May 2017, J. Marciniuk (WSRP);

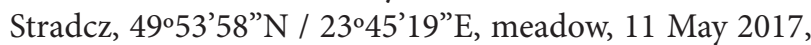
J. \& P. Marciniuk (WSRP, KRA); Lelechovka, Yavorivskiy National Park, 49 $56^{\prime} 45^{\prime \prime} \mathrm{N} / 2^{\circ} 41^{\prime} 21^{\prime \prime}$ E, meadow and sandy roadside in the forest, 11 May 2017, J. \& P. Marciniuk (WSRP, KRA).

\section{Taraxacum portentosum Kirschner \& Štěpánek, section Palustria (Asteraceae)}

Contributors - Jolanta Marciniuk, Paweł Marciniuk, Mateusz Wolanin

\section{Distribution and habitat}

Taraxacum portentosum is known chiefly from the area of Poland. Besides, it was also reported from few (probably no longer existing) locations in the Czech Republic and Slovakia (Kirschner and Štěpánek, 1998; Marciniuk and Marciniuk, 2006). We found three populations of the species in the Lviv region (western Ukraine). Taraxacum portentosum was recorded on extensively used wet meadows and waterlogged pastures. The populations of the species included several hundred individuals in total. Taraxacum portentosum should be considered as a new native species to Ukraine. Taraxacum portentosum is often recorded in the eastern Poland, so it is also probably quite a common species in the western part of Ukraine. 


\section{Taxonomic notes}

Taraxacum portentosum sect. Palustria (Figure 6) is included by Kirschner and Štěpánek (1998) to the group of Taraxacum fluviatile Kirschner \& Štěpánek and Taraxacum inundatum Kirschner \& Štěpánek. Taraxacum portentosum is closely related with Taraxacum fluviatile and Taraxacum ambrosium Kirschner \& Štěpánek. It clearly differs from the two mentioned species in the shape of the leaves - with irregular, narrow lateral lobes and very narrow interlobes. Taraxacum fluviatile and Taraxacum ambrosium have regularly arranged side lobes and wider interlobes. Main diagnostic features of Taraxacum portenosum are: $10-35 \mathrm{~cm}$; leaves almost stretched or raised, medium-green, deeply cut, lateral lobes usually 3-4 in number, deltoid with wide protruding base +/- abruptly tightened into narrow endings irregularly directed upwards or downwards, interlobes very narrow, usually entire or sparsely denticulate; terminal lobe triangular, hastate or triple, sometimes large; petiole narrow, purple scape pale greenish-brownish, below the capitulum densely covered with araneous hairs; capitulum $3.0-4.0 \mathrm{~cm}$ in diameter, flowers yellow; stigmas green; pollen present; the outer bracts numbering 16-21, more or less adpressed, in older capitulae often protruding, imbricate, ciliated, usually pale green, with very narrow, $0.3-0.6(-1.0) \mathrm{mm}$ wide central strip, often pink on the top, lanceolate or ovate-lanceolate (utmost external usually longitudinally lanceolate, not wider than $1.5 \mathrm{~mm}$ ), usually (7.0-)7.5-10.0 $\mathrm{mm}$ long and 2.0-3.5 mm wide; achenes 4.1-4.5(-4.8) $\mathrm{mm}$ long, spinulose on the top, gradually narrowed into more or less cylindrical cone, $0.9-1.2 \mathrm{~mm}$ long; rostrum 9.0-11.0 mm long; pappus 5.5-6.5 mm long.

Examined specimens (new records)

Ukraine: Novosilky, 49³8'42"N / 2401'19"E, wet pasture, 8 May 2017 M. Wolanin, K. Oklejewicz (KRA); Stradcz, 49॰54'02"N / 2345'34"E, wet meadow, 11 May 2017 J. \& P. Marciniuk, K. Oklejewicz (WSRP); between Lozina and Dabrovnitsa, 49॰57'02”N / 2348'45”E, wet meadow, 11 May 2017, J. \& P. Marciniuk (WSRP).

Taraxacum sinuatum Dahlst., section Taraxacum (Asteraceae)

Contributors - Jolanta Marciniuk, Paweł Marciniuk, Mateusz Wolanin

\section{Distribution and habitat}

Taraxacum sinuatum is a species with quite a broad range extending from France, the British Isles, the Netherlands, Denmark, Sweden, Norway, Finland, Latvia, to Germany, Poland, the Czech Republic and Slovakia (Kirschner and Štěpánek, 2007). A new locality of $T$. sinuatum was found in western Ukraine in 2017. The population of the species consists of about 50 individuals. Taraxacum sinuatum occurs in meadows and on grassy anthropogenic habitats. The species was found together with Taraxacum corynodes and Taraxacum lucidum on a wet meadow. We consider the species as a new and native to the flora of Ukraine

\section{Taxonomic notes}

Taraxacum sinuatum sect. Taraxacum (Figure 7) belongs to the Taraxacum lucidum group. Main diagnostic features of this taxon are: leaves medium green with broad, blunt, sometimes divided side lobes, their upper edges usually falcate, entire or with large teeth, lower edges straight or slightly concave with single large teeth; terminal lobe wide-triangular, blunt not larger from side lobes; petioles unwinged or very narrowly winged from the outside pale on the inside pink to lucidly purple; outer bracts horizontally, approximately $5 \mathrm{~mm}$ wide and $12-13 \mathrm{~mm}$ long, narrowly (sometimes faintly) bordered; capitulum convex ca. $45 \mathrm{~mm}$ in diameter; stigmas discolored; pollen present.

Examined specimens (new record)

Ukraine: Between Lozina and Dabrovnitsa, 4957'21.4”N / 2348'45.7”E, wet meadow, 11 May 2017, J. \& P. Marciniuk (WSRP).

Taraxacum subhuelphersianum M.P.Chr., section Taraxacum (Asteraceae)

Contributors - Jolanta Marciniuk, Paweł Marciniuk, Mateusz Wolanin

\section{Distribution and habitat}

Taraxacum subhuelphersianum is a species of poorly known distribution, previously reported from Finland, Norway, Sweden, Denmark, the Netherlands, Germany, the Czech Republic and Poland. It is considered to be alien to the flora of the British Isles (Kirschner and Štěpánek, 2007). Recently, we have found this species in one locality (30 individuals) at the Lychakiv cemetery in Lviv, Ukraine. We consider the species as a new and native to the flora of Ukraine. The species occurs in meadows and on grassy anthropogenic habitats.

Taxonomic notes

Taraxacum subhuelphersianum sect. Taraxacum (Figure 7) belongs to the Taraxacum retroflexum group. Main diagnostic features of this taxon are: petioles narrowly winged, from the outside pale on the inside red; leaves light green, side lobes recurved, deltoid, usually acute and entire on both edges; terminal lobe greater than side lobes blunt to acute without tip, often with one or two notches; outer bracts hanging, with clear margins, 3-4.5 mm wide; capitulum with a diameter of ca. $45 \mathrm{~mm}$, convex, dense; stigmas yellowish; pollen absent.

Examined specimens (new record)

Ukraine: Lviv, Lychakiv Cemetery, lawn 4949'56”N / 2403'11'E, 8 May 2017, J. \& P. Marciniuk (WSRP).

Taraxacum telmatophilum Kirschner \& Štěpánek, section Palustria (Asteraceae)

Contributors - Jolanta Marciniuk, Paweł Marciniuk, Mateusz Wolanin 


\section{Distribution and habitat}

Taraxacum telmatophilum is a very rare Pannonian species occurring in the southern part of Slovakia, in Hungary, and in a few localities in Austria, and eastern Poland (Kirschner and Štěpánek, 1998) Taraxacum telmatophilum is confined to subhalophilous vegetation, often growing along canals or shores of small ponds in pastures (Kirschner and Štěpánek, 1998). A new locality of T. telmatophilum was found in western Ukraine in 2017. It was recorded in wet pastures. We considered T. telmatophilum as a new native species to the flora of Ukraine. Discovered populations are located between the northern and southern part of the species' range.

Taxonomic notes

Taraxacum telmatophilum sect. Palustria (Figure 6) belongs to the group of Taraxacum cognatum Kirschner \& Štěpánek and Taraxacum telmatophilum (Kirschner and Štěpánek, 1998). Taraxacum telmatophilum is the most similar to Taraxacum potor Kirschner \& Štěpánek. The two species differ in the shape of leaves. The leaves of Taraxacum telmatophilum are lobed whereas those of Taraxacum potor are usually not lobed, but only lobulate or dentate.

Main diagnostic features of Taraxacum telmatophilum are: plants slender, $10-20 \mathrm{~cm}$ high; leaves usually nearly erect, greyish-green, usually shallowly lobed, more rarely only denticulate; lateral lobes (small lobes, teeth) usually $3-4(-5)$, protruded at the right angle, narrowly triangular or nearly linear (in young plants developing under extreme conditions), irregularly denticulate or small-lobed, upper edge usually concave; interlobes denticulate and smalllobed; petiole narrow, pale purple; scape brownish-purple, covered with araneous hairs; capitulum $2.5-3.0 \mathrm{~cm}$ in diameter, flowers yellow; stomata green, pollen present; the outer bracts (10-)13-15, adpressed to loosely adpressed, not imbricate, ciliated, blackish, narrowly lanceolate or lanceolate (6.5-)7.0-8.0(-9.5) mm long, (2.7-)2.9-3.3 mm wide; border of bracts distinctly limited to whitish narrow $0.2-0.3 \mathrm{~mm}$ wide edge; achenes $4.2-4.5 \mathrm{~mm}$ long, evidently spinulose on the top, fairly rapidly narrowing into $+/$ cylindrical cone $0.9-1.0 \mathrm{~mm}$ long; rostrum $7.0-8.0 \mathrm{~mm}$ long; pappus 5.5-6.0 mm long.

Examined specimens (new record)

Ukraine: Novosilky, 49³8'42"N / 2401'19"E waterlogged pasture, 8 May 2017 M. Wolanin, K. Oklejewicz (KRA).

\section{Taraxacum undulatiforme Dahlst., section} Taraxacum (Asteraceae)

Contributors - Jolanta Marciniuk, Paweł Marciniuk, Mateusz Wolanin

\section{Distribution and habitat}

Taraxacum undulatiforme is a species with poorly known distribution range, previously reported from France, Belgium, the Netherlands, Denmark, Norway, Sweden, Estonia, Germany, the Czech Republic, Slovakia and Poland (Kirschner and Štěpánek, 2007). A new locality of T. undulatiforme was found in the westerm Ukraine in 2017. It occurs in meadows and on grassy anthropogenic habitats. We considered T. undulatiforme as new, native species to the flora of Ukraine.

\section{Taxonomic notes}

Taraxacum undulatiforme sect. Taraxacum (Figure 7) in terms of morphology belongs to the Taraxacum lucidum group. Taraxacum undulatiforme is very similar to Taraxacum undulatum, from which it differs by the absence of distinct margin of the outer bracts, which are narrower and longer 4-4.9 mm wide and 13-15 $\mathrm{mm}$ long (Taraxacum undulatum: $5 \mathrm{~mm}$ wide and 12-13 $\mathrm{mm}$ long).

Examined specimens (new record)

Ukraine: Wola, 49³2'13"N / 2401'14"E, dry grassland with Orchis morio, 10 May 2017, J. Marciniuk (WSRP).

Taraxacum undulatum H.Lindb. \& Marklund, section Taraxacum (Asteraceae)

Contributors - Jolanta Marciniuk, Paweł Marciniuk, Mateusz Wolanin

Distribution and habitat

Taraxacum undulatum is a species reported from France, the British Isles, Belgium, the Netherlands, Denmark, Germany, Poland, the Czech Republic, Slovakia, Norway, Sweden, Finland, Latvia and the northern part of European Russia (Kirschner and Štěpánek, 2007). A few localities of T. undulatum were found in Ukraine during field studies conducted in 2017. These are the first records of the species for this country. It was met in meadows and on grassy anthropogenic habitats. T. undulatum is probably a fairly common species in the western Ukraine. We considered the species as native to the flora of Ukraine.

Taxonomic notes

Taraxacum undulatum sect. Taraxacum (Figure 6) belongs to the Taraxacum lucidum group. Main diagnostic features of this taxon include: leaves stout medium green, side lobes recurved, blunt, upper edges convex, undivided, lower edges straight or concave with a single large tooth; terminal lobe blunt broadly triangular; petioles green, winged; outer bracts horizontal, large area $5 \mathrm{~mm}$ wide and $12-13 \mathrm{~mm}$ long, clearly bordered; capitulum convex, 45-50 mm in diameter; stigmas discolored; pollen present.

Examined specimens (new records)

Ukraine: Stradcz, 4954'02.2”N / 2345'34.0”E, grazed meadow, 11 May 2017, J. \& P. Marciniuk (WSRP); Iwano-Franko, 4954'36"N / 2344'33"E, meadow over the Wereszczyca River, 11 May 2017, J. \& P. Marciniuk (WSRP); between Lozina and Dabrovnitsa, 49 57'21.4” N / 2348'45.7”E, wet meadow, 11 May 2017, J. \& P. Marciniuk (WSRP); Hodortivts (Hodorkowce), 49³5'00.1"N / $24^{\circ} 16^{\prime} 46.0^{\prime \prime E}$, wet pasture, 12 May 2017, K. Oklejewicz, M. Wolanin (KRA). 
Viscum album L. subsp. austriacum (Wiesb.) Vollm. (Santalaceae)

Contributors - Giacomo Mei, Adriano Stinca

Distribution and habitat

Viscum album subsp. austriacum is an Eurasian taxon. Its range is still not fully known (Zuber, 2004). It is widely distributed in all countries of central and southern Europe (Uotila, 2011). It was noted on Mount Etna in Sicily one century ago (as Viscum album L. $\gamma$ laxum Boiss. et Reut. (Fiori, 1923)). Later its occurrence in the flora of the island was considered doubtful (Giardina et al., 2007) thus it was not given in the Italian check-lists (Conti et al., 2005; Bartolucci et al., 2018). However, the presence of V. album subsp. austriacum was confirmed on Mount Etna in 2018.

Viscum album subsp. austriacum is a hemi-parasitic, dioecious shrub growing predominantly in mountain areas on the branches of some coniferous trees (Pinus spp., rarely Picea spp. and Larix spp.). On Mount Etna it was found in pioneer Corsican pine forest (Camerano et al., 2011) in communities of Junipero hemisphaericae-Pinetum calabricae Brullo \& Siracusa and other pioneer associations occurring on lavic materials.

\section{Taxonomy}

The cosmopolitan genus Viscum L. includes approximately 100 species (Zuber, 2004) two of which are recorded in Europe: Viscum album L. and Viscum cruciatum Boiss. Viscum album is divided into several commonly accepted subspecies, which are morphologically very similar, but parasitize different host species. In Europe, four subspecies are recognized (Zuber, 2004; Uotila, 2011; Böhling et al., 2002): Viscum album subsp. album that parasites on on deciduous trees; Viscum album subsp. abietis (Wiesb.) Abrom. that parasites solely on Abies spp.;

\section{References}

Andreev AI, Yusopova T (2015). Pyotr Kuz'mich Kozlov, 1863-1935. Geographers Biobibliographical Studies 34: 127-164.

Arthan W, Traiperm P, Gale SW, Norsaengsri M, Kethirun L (2016). Re-evaluation of the taxonomic status of Hackelochloa (Poaceae) based on anatomical and phenetic analyses. Botanical Journal of the Linnean Society 181: 224-245.

Artyukova EV, Kozyrenko MM, Boltenkov EV, Gorovoy PG (2014). One or three species in Megadenia (Brassicaceae): insight from molecular studies. Genetica 142 (4): 337-50. doi: 10.1007/ s10709-014-9778-1

Ball PW, Akeroyd JR (2010). Petrorhagia (Ser. Ex DC.) Link. In: Tutin TG, Heywood VH, Burges NA, Moore DM, Valentine DH, Walters SM, Webb DA (editors). Flora Europaea, Vol. 2, Rosaceae to Umbelliferae, UK: Cambridge University Press; pp. 224-227.
Viscum album subsp. austriacum that, as mentioned before, is found on Pinus spp. or rarely Picea spp. and Larix spp.; Viscum album subsp. creticum N.Böhling, Greuter, Raus, B.Snogerup, Snogerup \& Zuber which grows on Pinus halepensis Mill. subsp. brutia (Ten.) Holmboe exclusively in Crete.

\section{Examined specimens (new record)}

Italy: Sicily, Mt. Etna, province of Catania, Linguaglossa in locality Mt. Conca, UTM WGS84: $33 \mathrm{~N}$ zone, $37^{\circ} 47^{\prime} 22.95^{\prime \prime} \mathrm{N}$ / 1502’30.05”E, alt. 1805 m a.s.l., ENE exp., parasite Pinus nigra J.F.Arnold subsp. laricio Palib. ex Maire, 7 April 2018, G. Mei \& A. Stinca (ANC, PORUN-Herb. Stinca).

\section{Acknowledgements}

Research visits of Beata PASZKO to Beijing (PE) in 2017 and 2018 were supported by the exchange programme between the Polish Academy of Sciences and the Chinese Academy of Sciences; Jolanta MARCINIUK and Paweł MARCINIUK's research was carried out under the research theme No. $78 / 20 / \mathrm{B}$ financed from the science grant granted by the Ministry of Science and Higher Education; Anna WRÓBEL's research was supported by the Polish Ministry of Science and Higher Education via the Diamond Grant programme (decision no. 0207/DIA/2018/47); Gergely Király's researches were supported by the EFOP-3.6.1-16-2016-00018 project; Marcin NOBIS's researches were financially supported by the National Science Centre, Poland based on the decision UMO-2018/29/B/NZ9/00313 and in part, by the Institute of Botany of the Jagiellonian University K/ZDS/008058.

\section{Contribution of authors}

All the authors contributed in the field studies and preparation of selected parts of the manuscript. Marcin NOBIS, in the project coordinator.
Barina Z, Pifkó D, Rakaj M (2015). Contributions to the flora of Albania 5. Studia Botanica Hungarica 46: 119-140. doi:10.17110/StudBot.2015.46.2.119

Bartolucci F, Peruzzi L, Galasso G, Albano A, Alessandrini A et al. (2018). An updated checklist of the vascular flora native to Italy. Plant Biosystems 152 (2): 179-303. doi: 10.1080/11263504.2017.1419996

Beck G (1890). Monographie der Gattung Orobanche. Bibliotheca Botanica 19. Germany: Verlag von Theodor Fischer, Cassel (in Deutsch).

Berkutenko AN (1998). On the genus Megadenia (Brassicaceae). Botanicheskii Zhurnal 83: 69-72.

Böhling N, Greuter W, Raus T, Snogerup B, Snogerup S et al. (2002). Notes on the Cretan mistletoe, Viscum album subsp. creticum subsp. nova (Loranthaceae/Viscaceae). Israil Journal of Plant Sciences 50: 77-84. 
Bondarenko ON (1971). Petrorhagia Link. In: Kovalevskaya SS (editor). Conspectus florae Asiae Mediae, Vol. 2. Tashkent, Uzbekistan: Science Publishers, pp. 293-294 (in Russian).

Camerano P, Cullotta S, Varese P (editors) (2011). Strumenti conoscitivi per la gestione delle risorse forestali della Sicilia. Tipi Forestali. Regione Siciliana. Città di Castello (Perugia), Italy: Litograf Editor S.r.l.

Carlón L, Gómez Casares G, Laínz M, Moreno Moral G, Sánchez Pedraja Ó et al. (2008). Más, a propósito de algunas Phelipanche Pomel, Boulardia F. W. Schultz y Orobanche L. (Orobanchaceae) del oeste del Paleártico. Documentos del Jardín Botánico Atlántico (Gijón) 6: 1-128 (in Spanish with an abstract in English).

Carlón L, Gómez Casares G, Laínz M, Moreno Moral G, Sánchez Pedraja Ó et al. (2005). Más, a propósito de algunas Orobanche L. y Phelipanche Pomel (Orobanchaceae) del oeste del Paleártico. Documentos del Jardín Botánico Atlántico (Gijón) 3: 1-71 (in Spanish with an abstract in English).

Carlón L, Gómez-Casares G, Laínz M, Moreno Moral G, SanchezPedraja Ó (2002). A propósito de algunas Orobanche (Orobanchaceae) del noroeste peninsular y de su tratamiento en Flora iberica vol. XIV (2001). Documentos del Jardín Botánico Atlántico (Gijón) 1: I-IV+1-44 (in Spanish with an abstract in English).

Carlón L, Gómez-Casares G, Laínz M, Moreno Moral G, SanchezPedraja Ó (2003). Más, a propósito de algunas Orobanche (Orobanchaceae) del norte y este de la Península Ibérica. Documentos del Jardín Botánico Atlántico (Gijón) 2: 1-45 (in Spanish with an abstract in English).

Carlón L, Laínz M, Moreno Moral G, Sanchez-Pedraja Ó (2011). A new species (Orobanche loscosii), a priority name for O. icterica (O. leptantha) and a new member of the spanish flora $(O$. elatior). Flora Montiberica 48: 89-101.

Clayton WD, Renvoize SA (1986). Genera Graminum: grasses of the world. Kew Bulletin Additional Series 13. Oxford, UK: Clarendon Press.

Clement EJ, Foster MC (1994). Alien plants of the British Isles. London, UK: Botanical Society of the British Isles.

Conti F, Abbate G, Alessandrini A, Blasi C (editors) (2005). An Annotated Checklist of the Italian Vascular Flora. Roma, Italy: Palombi Editori.

Correll DS, Correll HB (1982). Flora of the Bahama Archipelago. Vaduz, Liechtenstein: Ganter.

Edmonds JM, and Chweya JA (1997). Black nightshades. Solanum nigrum L. and related species. In: Promoting the conservation and use of underutilized and neglected crops. Vol. 15. Gatersleben, Germany: Institute of Plant Genetics and Crop Plant Research \& Rome: International Plant Genetic Resources Institute.

Edmonds JM (1986). Biosystematics of Solanum sarrachoides Sendtner and S. physalifolium Rusby (S. nitidibaccatum Bitter). Botanical journal of the Linnean Society 92 (1): 1-38. doi: 10.1111/j.1095-8339.1986.tb01425.x
Euro+Med Plantbase (2018). The Information Resource for EuroMediterranean Plant Diversity [online]. Website http://www. emplantbase.org [accessed 31 January 2019].

Fang R, Staples G (1995). Convulvulaceae. In: Wu ZY, Raven PH (editors). Flora of China, Vol. 16. Beijing, China: Science Press, and St. Louis, USA: Missouri Botanical Garden Press, pp. 271325.

Fiori A (1923). Nuova Flora Analitica d'Italia contenente la descrizione delle piante vascolari indigene, inselvatichite e largamente coltivate in Italia. Vol. 1. Firenze, Italy: Tipografia di M. Ricci (in Italian).

Giardina G, Raimondo FM, Spadaro V (2007). A catalogue of plants growing in Sicily. Bocconea 20: 5-582.

Gillespie LJ, Soreng RJ, Bull RD, Jacobs SWL, Refulio-Rodriguez NF (2008). Phylogenetic relationships in subtribe Poinae (Poaceae, Poeae) based on nuclear ITS and plastid trnT-trnL-trnF sequences. Botany 86: 938-967.

Grubov VI (1963). Plantae Asiae Centralis. Vol. 1, Praefatio. Filicales. Bibliographia. Leningrad (St. Petersburg), Russia: Nauka (in Russian).

Grubov VI (1982). Opredelitel' sosudistykh rastenij Mongolii (s atlasom). Leningrad (St. Petersburg), Russia: Nauka (in Russian).

Hempel W (2011). Revision und Phylogenie der Arten der Gatung Melica L. (Poaceae) in Eurasien und Nordafrika. Feddes repertorium 122 (1-2): 1-253.

Holub J (1991). Eight new Rubus species described from Czech Republic. Folia geobotanica \& phytotaxonomica 26: 331-340.

Hsu CC, Kuoh CS, Liu HY (2000). Gramineae (Poaceae). In: Huang TC, Boufford DE, Hsieh CF, Kuoh CS, Ohashi H, Su HJ (editors). Flora of Taiwan. Vol. 5, 2nd ed. Taipei, Taiwan: National Taiwan University, pp. 318-654.

Hsui CC (1971). A guide to the Taiwan grasses, with keys to subfamilies, tribes, genera and species. Taiwania 16: 199-341.

Huang J, Chen J, Ying J, Ma K (2011). Features and distribution patterns of Chinese endemic seed plant species. Journal of systematics and evolution 49: 81-94. doi: 10.1111/j.17596831.2011.00119.x

Kamelin RV (editor) (1998). Spisok sosudistykh rastenii Kazakhstana (Checklist of Vascular Plants of Kazakhstan). Alma-Ata, Kazakhstan: Institute of Botany and Plant Introduction, p. 135 (in Russian).

Keng YL (1959). Aulacolepis Hackel. In: Keng YL (editor). Flora Illustralis Plantarum Sinicarum Gramineae. Beijing, China: Science Press, pp. 559-561.

Kirschner J, Štěpánek J (1998). Monograph of Taraxacum sect. Palustria. Průhonice, Czech Republic: Institute of Botany, Academy of Sciences.

Kirschner J, Štěpánek J, Greuter W (2007). “Taraxacum.” In Compositae. Euro+Med Plantbase - the information resource for Euro-Mediterranean plant diversity, edited by W. Greuter, E. von Raab-Straube [accessed 2018]. 
Korthof HM, Veldkamp JF (1984). A revision of Aniselytron with some new combinations in Deyeuxia in SE Asia (Gramineae). The Gardens' Bulletin, Singapore 37: 213-223.

Krahulcová A, Trávníček B, Šarhanová P (2013). Karyological variation in the genus Rubus, subgenus Rubus: new data from the Czech Republic and synthesis of the current knowledge of European species. Preslia 85: 19-39.

Kress WJ, DeFilipps RA, Farr E, Kyi DYY (2003). A checklist of the trees, shrubs, herbs and climbers of Myanmar (revised from the original works by J. H. Lace and H. G. Hundley). Contributions from the United States National Herbarium 45: 1-590.

Kurtto A, Weber HE, Lampinen R, Sennikov AN (editors) (2010). Atlas Florae Europaeae. Distribution of vascular plants in Europe, Vol. 15, Rosaceae (Rubus). Helsinki, Finland: The Committee for Mapping the Flora of Europea \& Societas Biologica Fennica Vanamo.

Lazkov GA, Sennikov AN (2017) Taxonomic corrections and new records in vascular plants of Kyrgyzstan, 5. Memoranda Societatis pro Fauna et Flora Fennica 93: 79-100.

Lazkov GA, Sultanova BA (2014). Checklist of vascular plants of Kyrgyzstan, 14. Bishkek, Kyrgyzstan: United Nations Development Programme.

Liang L, Tzvelev NN (2006). Puccinellia Parl. In: Zhengyi W, Raven $\mathrm{PH}$, Deyuan H (editors). Flora of China, Vol. 22. Beijing, China: Science Press and St. Louis, USA: Missouri Botanical Garden Press, pp. 245-256.

Lingdi LD, Boufford E (2003). Rubus Linnaeus. In: Wu ZY, Raven PH, Hong DY (editors). Flora of China, Vol. 9. Beijing, China: Science Press and St Louis, USA: Missouri Botanical Garden Press, pp. 195-285.

Liu SW (1987). Aulacolepis Hack. In: Kuo PC (editor). Flora Reipublicae Popularis Sinicae, Vol. 9 (3). Beijing, China: Science Press, p. 185-186 (in Chinese).

Lu SL, Phillips SM (2006). Aniselytron Merrill. In: Wu ZY, Raven PH, Hong DY (editors). Flora of : Poaceae, Vol 22. Beijing, China: Science Press and St. Louis, USA: Missouri Botanical Garden Press, pp. 310-311.

Ma HY, Peng H, Li DZ (2005). Taxonomic significance of leaf anatomy of Aniselytron (Poaceae) as an evidence to support its generic validity against Calamagrostis s. 1. Journal of Plant Research 118: 401-414. doi:10.1007/s10265-005-0236-0

Malyshev LI (2008). Megadenia malen’kaya. In: Trutnev YuP (editor). Krasnaya kniga Rossiiskoi Federatsii (rasteniya i griby) [The Red Data Book of the Russian Federation: Plants and Fungi]. Moscow, Russia: KMK, pp. 145-146 (in Russian).

Marciniuk J, Marciniuk P (2006). New sites of Taraxacum portentosum Kirschner \& Štěpánek and Taraxacum vindobonense Soest against a background of their distribution in Poland. Biodiversity Research and Conservation 3-4: 304-307.

Marciniuk J, Vašut RJ, Marciniuk P, Czarna A (2009). Taraxacum scanicum Dahlst. group (section Erythrosperma) in Poland: chorology and seed and pollen morphology of the microspecies. Acta Societatis Botanicorum Poloniae 78 (2): 115-121. doi: 10.5586/asbp. 2009.015
Martinovský JO (1980). Stipa L. In: Tutin TG, Heywood VH, Burges NA, Moore DM, Valentine DH, Walters SM, Webb DA (editors). Flora Europaea, Vol. 5. Cambridge, UK: Cambridge University Press, pp. 247-252.

Mayorov SR (2014). Solanaceae Juss. In: Mayevsky PF (editor). Flora srednei polosy Evropeiskoi chasti Rossii [Flora of the Central Part of the European Russia], 11th ed. Moscow, Russia: KMK Scientific Press, pp. 390-394 (in Russian).

Medvecká J, Kliment J, Májeková J, Halada L, Zaliberová M et al. (2012). Inventory of the alien flora of Slovakia. Preslia 84: 257309.

Melnikov DG (2011). New floristic findings of native and adventive species in Udmurtia. Bulletin of Udmurt University: Series Biology, Earth Sciences 3: 142-146.

Merrill ED, Merritt ML (1910). The flora of Mount Pulog. The Philippine Journal of Science, Section Botany 5: 287-403.

Milović M, Mitić B (2012). The urban flora of the city of Zadar (Dalmatia, Croatia). Natura Croatica 21: 65-100.

Nobis M, Domina G, Meço M, Mullaj A, Bazan G et al. (2018). Contribution to the flora of Asian and European countries: new national and regional vascular plant records, 7. Botany Letters 165 (2): 200-222. doi: 10.1080/23818107.2017.1415817

Nobis M, Klichowska E, Nowak A (2017). Proposal to conserve the name Stipa pulcherrima (Poaceae) with a conserved type. Taxon 66 (2): 518-519.

Nobis M, Klichowska E, Terlević A, Wróbel A, Erst A et al. (2019). Contribution to the flora of Asian and European countries: new national and regional vascular plant records, 8. Botany Letters 166 (2): 163-188. doi: 10.1080/23818107.2019.1600165

Nobis M., Gudkova PD, Nowak A, Sawicki J, Nobis A (2020). A synopsis of the genus Stipa (Poaceae) in Middle Asia, including a key to species identification, an annotated checklist and phytogeographic analyses. Annals of the Missouri Botanical Garden 105. doi: 10.3417/2019378

Noltie HJ (2000). Flora of Bhutan, Vol. 3 (2). Edinburgh, UK: Royal Botanic Garden Edinburgh \& Royal Government of Bhutan.

Ohwi J (1933). Symbolae ad Floram Asiae Orientalis, 9. Acta Phytotaxonomica et Geobotanica 2 (3): 149-170.

Ohwi J (1935). Symbolae ad Floram Asiae Orientalis, 11. Acta Phytotaxonomica et Geobotanica 4 (1): 30-34.

Ostroumova TA, Berkutenko AN (2010). How many species does the genus Megadenia (Cruciferae) contain? - stomatographical data. In: Verkhozina AV (editor). Problemy izucheniya i sokhraneniya rastitel'nogo mira Evrazii [The problem of research and conservation of vegetable kingdom of Eurasia]. Irkutsk, Russia: Inst. Geografii im. V.B. Sochavy SO RAN, pp. 262-265 (in Russian).

Otto R, Verloove F (2016). New xenophytes from La Palma (Canary Islands, Spain), with emphasis on naturalized and (potentially) invasive species. Collectanea Botanica 35: e001. doi: 10.3989/ collectbot.2016.v35.001 
Ovchinnikov PN (1957). Puccinellia Parl. In: Ovchinnikov PN (editor). Flora Tadzhikskoi SSR, Vol. 1, Paprotnikoobraznye Zlaki. Moscow-Leningrad, Russia: Izdatelstvo Akademii Nauk SSSR, pp. 223-232 (in Russian).

Ovchinnikov PN (1968). Flora Tadzhikskoi SSR, Vol. 3. Opekhovye Gvozdichnye. Leningrad, Russia: Izdatelstvo Nauka.

Paszko B, Liu B, Ma HY (2017). Calamagrostis (Poaceae, Agrostidinae) in Vietnam. Polish Botnical Journal 62 (2): 213228. doi: $10.1515 / \mathrm{pbj}-2017-0013$

Paszko B, Soreng RJ (2013). Species delimitation and name application in Deyeuxia abnormis, Agrostis zenkeri, A. pleiophylla and related taxa (Poaceae: Agrostidinae). Phytotaxa 111: 1-26. doi: 10.11646/phytotaxa.111.1.1

Pavlov NW (1936). Atraphaxis L. In: Komarov WL (editor). Flora URSS, Vol. 5. Moscow-Leningrad, Russia: Izdatelstvo Akademii Nauk SSSR, pp. 501-527 (in Russian).

Petrović S (1885). Dodatak flori okoline Niša [Additamenta ad floram agri Nyssani]. Belgrade, Serbia: Kraljevsko-srpska državna štamparija.

Piwowarczyk R (2016). Phelipanche lavandulacea (Rchb.) Pomel (Orobanchaceae). In: Nobis M, Nowak A, Piwowarczyk R, Ebel AL, Király G et al. Contribution to the flora of Asian and European countries: new national and regional vascular plant records, 5. Botany Letters 163 (2): 159-174.

Probatova NS, Kazanovsky SG, Rudyka EG, Seledets VP, Ovchinnikova SV (2013). Puccinellia schischkinii Tzvelev. In: Marhold K, Breitwieser I, editors. IAPT/IOPB chromosome data 16. Taxon 62 (6): 1356-1361. doi: 10.12705/626.41

Raab-Straube E. von, Raus T. (2019a) Euro+Med-Checklist Notulae, 10. Willdenowia 49 (1): 95-115.

Raab-Straube E. von, Raus T. (2019b) Euro+Med-Checklist Notulae. Willdenowia 11. 49 (3): 421-445.

Reichenbach HGL (1829). Iconographia botanica seu plantae criticae [...]. Septima centuria tabularum: 29-50, 651-700. Leipzig, Germany: Apud Fidericum Hofmeister (in Latin).

Reuter G (1847). Orobanchaceae. In: De Candolle A (editor). Prodromus systematis naturalis. Regni vegetabilis sive enumeratio contracta ordinum, generum, specierumque plantarum, 11: 1-45. Addenda et Corrigenda: 717-720. Parisiis, France: Sumptibus Victoris Masson (in Latin).

Sánchez Pedraja Ó, Moreno Moral G, Carlón L, Piwowarczyk R, Laínz M et al. (2016+). Index of Orobanchaceae. Liérganes, Cantabria, Spain: ISSN: 2386-9666.

Schultz FW (1842-1855). Notice sur quelques espèces de la famille des Orobanchacées, décrites par M. Reuter dans le onzième volume du Prodromus systematis naturalis regni vegetabilis de DC., \& sur un genre nouveau de cette famille non encore mentionné dans les ouvrages de botanique. Archives de la flore de France \& d'Allemagne. 1 Vol. + 99-105. Bitche, France: Chez l'auteur; 1842-1855. [1-48(1842), 49-76 (1844), 77-98 (1846), 99-154 (1848), 155-166 (1850), 167-194 (1851), 195258 (1852), 259-282 (1853), 283-326 (1854), 327-350 (1855)] (in French).
Selvaggi A, Soldano A, Pascale M, Dellavedova R (2013). Note floristiche piemontesi n. 460-544. Rivista piemontese di Storia naturale 34: 389-437 (in Italian with an English abstract).

Shukla U (1996). The grasses of north-eastern India. Jodphur, IN: Scientific Publishers.

Silvestre S (2012). Dichondra J.R. Forst. \& G. Forst. In: Castroviejo S. et al. (editors). Flora iberica, Vol. 11. Madrid, Spain: Real Jardín Botánico, CSIC, pp. 289-292.

Soreng RJ, Peterson PM, Romaschenko K, Davidse G, Zuloaga FO, Judziewicz EJ, Filgueiras TS, Davis JI, Morrone O (2015). A worldwide phylogenetic classification of the Poaceae (Gramineae). Journal of Systematics and Evolution 53: 117137. doi: $10.1111 /$ jse. 12150

Sun BX, Phillips SM (2006). Hackelochloa Kuntze. In: Wu ZY, Raven $\mathrm{PH}$, Hong DY (editors). Flora of China, Vol. 22, Poaceae. Beijing, China: Science Press and St. Louis, USA: Missouri Botanical Garden Press, pp. 646-647.

Tafra D, Milović M, Pandža M (2013). Non-native flora of the town of Omiš (Dalmatia, Croatia). Natura Croatica 22: 135-146.

Tharp BC, Johnston MC (1961). Recharacterization of Dichondra (Convolvulaceae) and a revision of the North American species. Brittonia. 13: 346-360. doi: 10.2307/2805413

Trávníček B, Zázvorka J (2005). Taxonomy of Rubus ser. Discolores in the Czech Republic and adjacent regions. Preslia 77: 1-88.

Tutin TG (1980). Melica L. In: Tutin TG, Heywood VH, Burges NA, Moore DM, Valentine DH et al. (editors). Flora Europaea, Vol. 5, Alismataceae to Orchidaceae (Monocotyledones). Cambridge, UK: Cambridge University Press, pp. 178-179.

Tyler T (2002). Large-scale geographic patterns of genetic variation in Melica nutans, a widespread Eurasian woodland grass. Journal of Systematics and Evolution 236: 73-87.

Tzvelev NN (1968). Plantae Asiae Centralis, Vol. 4, Gramineae. Leningrad (St. Petersburg), Russia: Nauka..

Tzvelev NN (1976). Zlaki SSSR [Grasses of the USSR]. Leningrad, Russia: Nauka (in Russian).

Tzvelev NN (2006). Stipa L. In: Takhtajan AL (editor). Konspekt Flory Kavkaza. Vol. 2. Saint Petersburg, Russia: Saint-Petersburg University Press, pp. 348-356 (in Russian).

Uhlemann I (2004). New Species of the Genus Taraxacum (Asteraceae) from Germany I. Schlechtendalia 12: 119-136.

Uotila P (2011). “Loranthaceae." In Euro+Med Plantbase - the information resource for Euro-Mediterranean plant diversity [online]. Website http://ww2.bgbm.org/EuroPlusMed/ PTaxonDetail.asp NameId $=25275 \&$ PTRefFk $=7300000$ [Accessed 07 June 2018].

Vasjukov VM (2016). New species of Thymus L. (Lamiaceae). Novosti Sistematiki Nizshikh Rastenii 47: 108-115.

Veldkamp J, van den Boogaart MEB, Heidweiller J, van der Klaauw MAF, de Koning R, Kraaijeveld AR et al. (2013). A revision of Mnesithea (Gramineae - Rottboelliinae) in Malesia and Thailand. Blumea 58:277-292. doi: 10.3767/000651913X678257 


\section{NOBIS et al. / Turk J Bot}

Veldkamp JF, de Koning R, Sosef MSM (1986). Generic delimitation of Rottboellia and related genera (Gramineae). Blumea 31: 281307.

Veldkamp JF (1994). Poa L. (Gramineae) in Malesia. Blumea 38: 409457.

Vorobyev DP, Voroshilov VN, Gorovoy PG (1976). A new species Megadenia Maxim. (Brassicaceae) in the Far East. Biulleten' Biull Gl Bot Sada (Moscow) 101: 58-61. doi: 10.1007/s10709014-9778-1

Weber HE (1995). Rubus L. In: Weber HE (editor). Gustav Hegi, Illustrierte Flora von Mitteleuropa, 4/2A Vol., 3rd ed. Berlin, Germany: Blackwell Wissenschafts-Verlag., pp. 284-595 (in German).

Wu ZL, Phillips SM (2006). Tribe Meliceae. In: Wu ZY, Raven PH, Hong DY (editors). Flora of China, Vol 22, Poaceae. Beijing, China: Science Press and St. Louis, USA: Missouri Botanical Garden Press, pp. 212-223.
Zhao NX (1995). Notes on the genus Aniselytron Merrill (Gramineae). Journal of Tropical and Subtropical Botany 3 (2): 47-51.

Zhou T, Lu L, Yang G, Al-Shehbaz IA (2001). Brassicaceae (Cruciferae). In: Wu CY, Raven PH (editors). Flora of China, Vol. 8. Beijing, China: Science Press and St. Louis, USA: Missouri Botanical Garden Press, pp. 1-193.

Zieliński J (2004). The genus Rubus (Rosaceae) in Poland. Polish Botical Studies 16: pp. 1-300.

Zuber D (2004). Biological flora of Central Europe: Viscum album L. Flora 199 (3): 181-203. doi: 10.1078/0367-2530-00147 